NBER WORKING PAPER SERIES

\title{
CENTRAL BANK CREDIBILITY, REPUTATION AND INFLATION TARGETING IN HISTORICAL PERSPECTIVE
}

\author{
Michael Bordo \\ Pierre Siklos \\ Working Paper 20693 \\ http://www.nber.org/papers/w20693 \\ NATIONAL BUREAU OF ECONOMIC RESEARCH \\ 1050 Massachusetts Avenue \\ Cambridge, MA 02138 \\ November 2014
}

This paper was first presented at the FLAR conference in Cartagena Colombia July 25 2014. The views expressed herein are those of the authors and do not necessarily reflect the views of the National Bureau of Economic Research.

NBER working papers are circulated for discussion and comment purposes. They have not been peerreviewed or been subject to the review by the NBER Board of Directors that accompanies official NBER publications.

(C) 2014 by Michael Bordo and Pierre Siklos. All rights reserved. Short sections of text, not to exceed two paragraphs, may be quoted without explicit permission provided that full credit, including $\odot$ notice, is given to the source. 
Central Bank Credibility, Reputation and Inflation Targeting in Historical Perspective Michael Bordo and Pierre Siklos

NBER Working Paper No. 20693

November 2014

JEL No. C32,C36,E31,E58,N10

\begin{abstract}
$\underline{\text { ABSTRACT }}$
This paper examines the historical evolution of central bank credibility using both historical narrative and empirics for a group of 16 countries, both advanced and emerging. It shows how the evolution of credibility has gone through a pendulum where credibility was high under the classical gold standard before 1914 before being lost and not fully regained until the 1980s. This characterization does not, however, seem to apply to the monetary history in the emerging markets examined in the paper. Nevertheless, credibility in all the economies examined has been enhanced in recent decades thanks to the adoption of inflation targeting. However, the recent financial crisis and the call for central banks to focus more on financial stability relying on macro prudential regulation may pose significant challenges for central bank credibility.
\end{abstract}

Michael Bordo

Department of Economics

Rutgers University

New Jersey Hall

75 Hamilton Street

New Brunswick, NJ 08901

and NBER

bordo@econ.rutgers.edu

Pierre Siklos

Wilfrid Laurier University

75 University Ave

Waterloo, ON, CANADA, N2L 3C5

psiklos@wlu.ca 


\section{Introduction}

Central bank credibility and reputation is an important topic in modern central banking. Central banks have been in existence since the seventeenth century. They have evolved from serving as government fiscal agents, to lenders of last resort, to preserving the gold standard nominal anchor, to providing macro stability, and currently to providing financial stability. Central bank credibility has waxed and waned through this period. In the past two decades, the credibility and reputation of central banks has been high, at least until the financial crisis of 2007-2008. An important contributor to the achievement of credibility has been the advent and adoption of inflation targeting by many countries.

The paper examines the historical evolution of central bank credibility using both historical narrative and empirics for a group of 16 countries, both advanced and emerging. It shows how the evolution of credibility has gone through a pendulum where credibility was high under the classical gold standard before 1914, then credibility was lost after 1914 and not fully regained until the 1980s. This process was further enhanced in the last two decades with the advent of IT. The recent financial crisis and the call for central banks to focus more on financial stability and especially use the tools of macro prudential regulation may pose significant challenges for central bank credibility.

In section 2 we define central bank credibility and reputation. In section 3 we then provide a general overview of the historical evolution of credibility over the past 
two centuries. Section 3 presents six historical case studies of central bank evolution. We examine the record of three important advanced countries: United States, United Kingdom and Germany; and three Latin American emerging countries. They are: Chile, Colombia and Mexico. In section 4 we turn to the measurement of credibility as the deviation between observed inflation and the implied objective rate of inflation derived from a Taylor Rule like framework. We provide evidence on central bank credibility and its determinants across three broadly demarcated policy regimes for a panel of 10 advanced countries. The regimes are: the gold standard; Bretton Woods and the recent era of low inflation since 1980. In section 5 we consider inflation targeting as a credibility enhancer based on enhanced transparency and communication. We conclude with reflections on the impact on central bank credibility of the recent emphasis on macro prudential regulation to provide financial stability.

\section{Definitions}

We define central bank credibility as a commitment to follow well-articulated and transparent rules and policy goals. More precisely, credibility refers to the “ ...extent to which the public believes that a shift in policy has taken place when, indeed, such a shift has actually occurred" (Cukierman 1986 page 6). More generally Karl Brunner (1983) made the connection between credibility and the performance of the institutions mandated to carry out policies: "Credibility depends ... on the history of policy making and the behavior of the policy institution." 
We interpret credibility in terms of inflation performance. Credibility is a flow like variable that changes as observed inflation is seen to deviate from a time varying inflation objective, which need not be explicit or publicly announced. Credibility is also partially determined by the relative importance the central bank attaches to real and nominal objectives. Regular economic shocks and the manner in which the central bank manipulates monetary policy dictate how credibility evolves over time. Credibility evolves in a non- linear manner, i.e. it is earned slowly and painstakingly yet is susceptible to evaporate on a moment's notice. In the words of Benjamin Franklin "It takes many good deeds to build a reputation, and only one bad one to lose it." Identifying and measuring credibility is challenging. Nevertheless, as Cukierman (1986, page 5) again points out “ ...the ability of monetary policymakers to achieve their future objectives depends on the inflationary objectives of the public. These inflationary expectations depend, in turn on the public's evaluation of the credibility of the monetary policy makers..." Paul Volcker, former Chairman of the Federal Reserve Board of Governors, once underscored the point "[T]o break the inflation cycle we must have credible and disciplined monetary policy" (Bernanke 2013 page 35). Indeed Volcker went on to remark that “... inflation undermines trust in government. " (Silber 2012, page 266). Therefore, autonomy, transparency, accountability, and the monetary policy strategy in place each can influence both the credibility and reputation of the monetary authority.

Credibility builds trust in institutions and helps weather crises. It also helps markets and the public discern the actual policies being followed. Key determinants of credibility are the monetary regime in effect and institutional factors such as the 
mandate of the central bank, its autonomy with respect to the government, the governance of the institution. These variables are crucial in understanding how a central bank is able to manage its credibility over time. ${ }^{2}$

To operationalize our definition of central bank credibility we argue, following Bordo and Siklos (2014) that a central bank is deemed credible when it delivers, subject to a random error, the implied inflation rate objective conditional on the monetary regime in place.

We write equation $(1) .^{3}$

$\left(\pi_{i t}-\bar{\pi}_{i t}\right)^{2}=\mathbf{\theta} \mathbf{Z}_{i t}+\varphi_{i}\left(\pi_{i, t-1}-\bar{\pi}_{i, t-1}\right)^{2}+\mathbf{u}_{i t}$

Where the dependent variable is our indicator $\mathbf{\theta} \mathbf{Z}_{i t}$ is the product of a vector of coefficients. $\boldsymbol{\theta}$ and $\mathbf{Z}_{i t}$ represents economic and institutional variables that can explain departures from the inflation target. Thus equation (1) expresses credibility as the squared differential between the observed inflation rate and the central bank's goal.

The basic idea behind our proxy for credibility can be explained intuitively. Readers interested in more technical details are asked to consult Bordo and Siklos (2014). We begin with the notion that the stance of monetary policy is set via an instrument of monetary policy. Over the long history of central banking it is fair to say that three such instruments have been dominant. They are: an exchange rate, as when the Gold Standard or the Bretton Woods regimes were in place, a monetary aggregate such as in, for example, the 1980s and early 1990s when the Bretton

\footnotetext{
${ }^{2}$ See Bordo and Siklos (2014)

${ }^{3}$ IBID
} 
Woods system was abandoned, and an interest rate instrument, in place when exchange rates floated and most countries adopted some kind of price stability objective.

Of course, actual monetary policy regimes likely were never purely operated as if, say, the exchange rate regime was a pure float or a strict peg. Moreover, theoretical economic models are capable of deriving equivalence results that permit one to think in terms of a central bank that operates as if a preferred instrument was in place. Hence, it is often the case today that the starting point for an analysis of monetary policy is the eponymous Taylor rule which expresses the stance of monetary policy as being a function of an inflation gap and an output gap and is also conditioned on a target constant neutral real interest rate.

Next, after allowing for a time-varying neutral real interest rate, inflation and output gaps, we can back out the implied target for inflation the central bank has in mind, conditional on the chosen instrument. In the case of an interest rate we simply follow a Taylor rule with interest rate smoothing. In the case of an exchange rate target we modify the Taylor rule to allow a response to a gap in the real exchange rate while a money growth target implies that an additional restriction, in the form of the quantity theory, is presumed to hold. Kozicki and Tinsley (2009) adopt this basic strategy although our approach differs somewhat from theirs by requiring the central bank to respond to an output gap, and not an unemployment gap, as well as by adding the possibility that the central bank also has an exchange rate target.

Note that when we examine the more recent inflation targeting period, and the connection between transparency and credibility highlighted in the introduction of 
the paper, a short sample together with data limitations requires us to simplify the previously discussed empirical strategy to obtain some illustrative econometric evidence.

\section{The historical pattern of credibility and reputation through the ages}

The history of central bank credibility is tied up with the history of policy regimes. We compare credibility in three broadly defined regimes: the gold standard which includes the pre 1914 classical gold standard; the Bretton Woods era which includes the years when the US indirectly adhered to the gold nominal anchor and the period afterwards when the gold anchor was raised leading to the Great Inflation and the recent fiat money regime with the primacy of low inflation since the 1980s. See Table 1 which demarcates the dates of adherence to each regime for 16 countries, both advanced and emerging. Figure 1 shows the patterns of expected and observed inflation for 10 countries for which we have data for each of the regimes. Figure 1 reveals a pendulum pattern: credibility was high in the gold standard era, less so in the Bretton Woods era and then back to the pattern of the gold standard under the current fiat money regime with primacy for low inflation.

Table 1. The Pendulum of Monetary Regimes in Select Economies Since the Early $1^{\text {th }}$ Century ${ }^{3}$

\begin{tabular}{|l|l|l|l|}
\hline Economy & Gold Standard & Bretton Woods & $\begin{array}{l}\text { Primacy of Price } \\
\text { Stability - Flexible } \\
\text { Monetary Regime } \\
\text { (Type) }\end{array}$ \\
\hline Sweden & $\begin{array}{l}1873-1914 \& 1922- \\
1931\end{array}$ & $1959-1974$ & 1993- (IT) \\
\hline United Kingdom & $\begin{array}{l}1821-1914 \& 1925- \\
1931\end{array}$ & $1959-1972$ & $1992-$ (IT) \\
\hline
\end{tabular}




\begin{tabular}{|c|c|c|c|}
\hline France & $\begin{array}{l}\text { 1878-1914 \& 1926- } \\
1936\end{array}$ & $1959-1973$ & 1993-(МаaT) \\
\hline Norway & $\begin{array}{l}1875-1914 \& \text { \& 1928- } \\
1931\end{array}$ & $1959-1972$ & 2001-(IT) \\
\hline Germany & $\begin{array}{l}1871-1914 \& 1924- \\
1931\end{array}$ & $1959-1973$ & 1993-(MT) \\
\hline Japan & $\begin{array}{l}1897-1917 \& 1930- \\
1931\end{array}$ & 1959-1977 & 1997-(Ind) \\
\hline Italy & $\begin{array}{l}1884-1917 \& 1927- \\
1934\end{array}$ & $1959-1972$ & 1993-(MaaT) \\
\hline Switzerland & $1878-1914$ & 1959-1972 & 1973-1 \\
\hline USA & $\begin{array}{l}1880-1917 \& 1922- \\
1933\end{array}$ & 1959-1972 & $1980^{-2}$ \\
\hline Chile & $\begin{array}{l}1895-1898 \& 1926- \\
1931\end{array}$ & $1959-1970$ & 1990-(IT) \\
\hline Mexico & $\begin{array}{l}1905-1913 \& 1921- \\
1931\end{array}$ & $1959-1976$ & 1999-(IT) \\
\hline Canada & $\begin{array}{l}1854-1914 \& 1926- \\
1929\end{array}$ & $1960-1970$ & 1991-(IT) \\
\hline New Zealand & $\begin{array}{l}1821-1914 \& 1925- \\
1930\end{array}$ & 1959-1973 & 1990-(IT) \\
\hline Argentina & $\begin{array}{l}1900-1914 \& 1927- \\
1929\end{array}$ & 1964-1970 & 1991-2002 (CBd) \\
\hline Australia & $\begin{array}{l}1852-1915 \& 1925- \\
1930\end{array}$ & 1959-1974 & 1993-(IT) \\
\hline Colombia & $1923-1932$ & 1959-1970 & 1999-(IT) \\
\hline
\end{tabular}

Sources: Gold Standard, http://www.carmenreinhart.com/data/browse-by-topic/topics/13/ (Carmen Reinhart's website); Breton Woods, type 1 or 2 exchange rate regime (de facto peg or pre-announced crawling peg), from Annual Fine Classification, http://www.carmenreinhart.com/data/browse-bytopic/topics/11/ (Carmen Reinhart's website). IT means a numerical inflation target, CBd signifies a currency board, Ind refers to the period since central bank independence, and MaaT is the Maastricht Treaty. Data from central bank websites via BIS's Central Bank Hub (http://www.bis.org/central_bank_hub_overview.htm). Also, data from Bordo and Eichengreen (1993). Notes: 1. End of Bretton Woods; 2. Volcker era monetary reforms; 3. Economies discussed in Bordo and Siklos (2014).

\section{Figure 1. Expected and observed inflation for 10 countries}



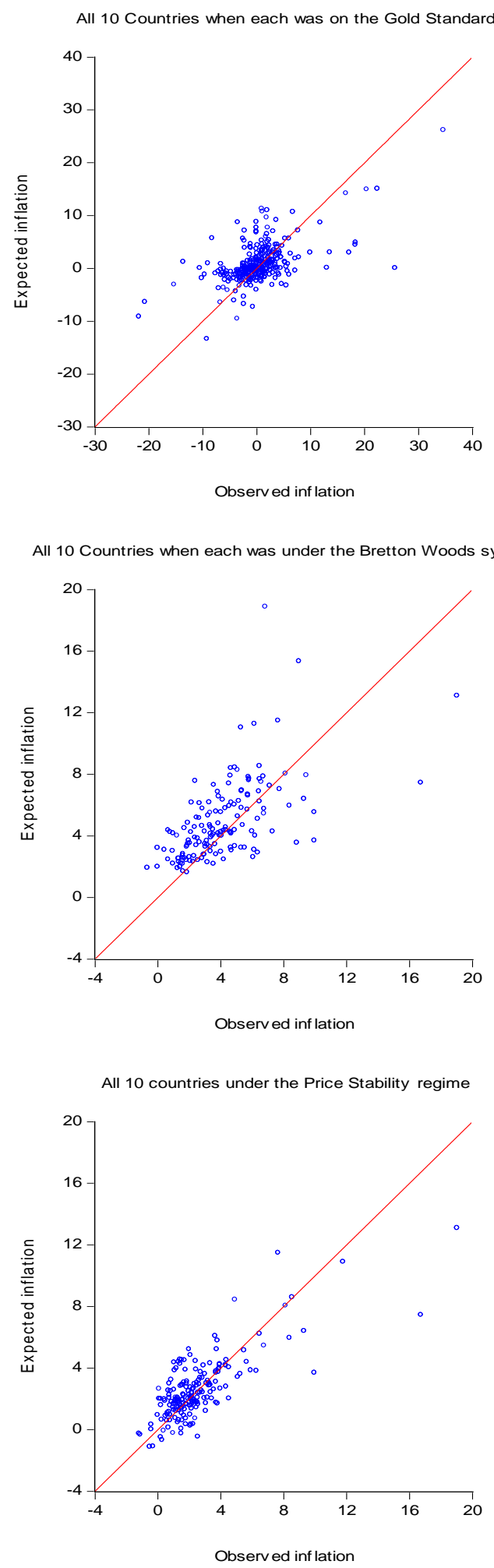

Note: the 10 countries refer to the ones in Bordo and Siklos (2014). They are the first 9 countries listed in Table 1 and Canada. 
The history of central bank credibility is tied up with the history of monetary policy regimes. The classical gold standard, which prevailed from 1880 to 1914, embodied a rule based on the commitment to maintain the official peg of domestic currency in terms of gold. Central banks of advanced countries, which in many cases were private institutions independent of the fiscal authorities generally adhered to this rule. The gold standard rule was a contingent rule where temporary suspensions and the issue of fiat money were permitted in well understood emergencies such as wars and financial crises. Once the emergency ended the central bank was required to restore convertibility to gold at the official parity. If it did this it would ensure its credibility (Bordo and Kydland 1995). Credible adherence to the gold standard rule allowed central banks to have some leeway to conduct stabilization policies within the gold points (Bordo and MacDonald 2012). It also insured that it could conduct lender of last resort actions without engendering capital flight (Eichengreen 1997). The history of the pre 1914 gold standard shows how important countries, especially Britain, France, Germany and the United States had credible regimes. Smaller Western European countries like Sweden, Belgium and the Netherlands also were credible. Other peripheral European countries like Italy, Spain and Portugal tried to gain credibility but were less successful as were all of the Latin American countries (Bordo and Schwartz 1994).

World War I ended the classical gold standard and, after the war, many countries tried to rebuild the prewar system. Restoring the prewar parity after massive wartime inflation and changes in the political economy (suffrage) delayed the restoration of the gold standard and the standard that was established-the fragile 
gold exchange standard—had less credibility. Britain returned to gold at the prewar parity in 1925 but at an overvalued parity which continually threatened its adherence. The U.S. never left gold but the newly established Federal Reserve went through a lengthy learning period to become a fully functioning member of the gold club (Meltzer 2002). France went through a period of high inflation and its central bank lost much of its credibility in a scandal. Germany went through a hyperinflation fueled by the Reichsbank.

By 1926 the gold exchange standard was up and running and its short-lived success depended upon the reputations of Benjamin Strong, Montagu Norman, Emile Moreau and Hjalmar Schacht. Despite their efforts the system collapsed during the Great Depression. In its aftermath central bankers were blamed for the Depression and central banks lost their independence and became virtual appendages of the fiscal authorities.

Central Banks regained fiscal independence from the fiscal authorities beginning in the 1950s. The Fed was the first. It regained independence in the Federal Reserve Treasury Accord of 1951 when, under Chairman William McChesney Martin it began following gold standard orthodoxy dedicated to price stability (see section 4 below). Few other central banks with the principal exceptions of the Bundesbank and the Swiss National Bank followed suit. The theme linking independence to credibility and the role of the policy regime in dictating central bank behavior is a recurrent one throughout the twentieth century (Siklos 2002).

In the U.S. the return to monetary orthodoxy rested on the reputation of Chairman Martin but the restoration of central bank credibility was, however, short-lived. In 
the 1960s central banks (with the exception of the Bundesbank and the SNB) began following Keynesian policies to maintain full employment at the expense of higher inflation. The subsequent Great Inflation destroyed any vestiges of credibility as well as the reputations of central bankers such as Arthur Burns (Bordo and Orphanides 2013). Paul Volcker's adoption of a monetarist style tight monetary policy in 1979 broke the back of inflationary expectations at the expense of a deep recession in the U.S. Previously, inflation had drifted upward in a seemingly permanent fashion (e.g. see Goodfriend and King 2013, and DeLong 1997) and it appears that only a form of 'shock therapy' could restore lower long-run inflationary expectations (e.g. see Levin and Taylor 2013).

Similar strategies were followed in Canada, the UK, Japan and other countries so that by the mid-1980s the Great Moderation restored price stability in the advanced countries along with the reputations of central bankers. However, in all of these instances (with the possible exception of Switzerland) credibility did not exist in the immediate postwar. It had to be earned at an economic price over time. Indeed the lower the credibility of policies, the more adverse the economic costs are (Fellner 1976, Haberler 1980). The commitment to rules focused on low inflation helped to restore central bank credibility (e.g., see Levin and Taylor (2013) and Goodfriend 1986). What helped these central banks to succeed was that new policies were built on the reputations of the institutions. In Germany, the Bundesbank (DBB) gained credibility and a sterling reputation in the postwar period. The DBB was founded in 1948 with the express mandate to pursue price stability. This mandate was a reaction to the disastrous experience of its predecessor, the Reichsbank, in 
generating a hyperinflation in the 1920s (see section 4 below).Thus the pendulum has swung towards greater central bank credibility in recent decades and in many ways the world has gone back to the future.

The financial crisis of 2007-2008 led to massive discretionary intervention in financial markets by central banks around the world. Many of the actions mixed monetary with fiscal policy and seemingly contradicted notions of violate central bank independence.

The changes in the legislative and regulatory landscape that followed have expanded the role of central banks. Time will tell if their credibility to maintain low inflation will survive. However, unlike earlier episodes in the monetary history of the last century or so, it is the fear of deflation and depression that has fueled central banks' responses. It is worth contemplating whether the ability of central banks to ease policies by historically unheard of amounts, without signs that inflationary expectations are becoming unanchored is a sign of the triumph of central banking credibility and underscores the strength of their reputation.

\section{Historical narratives on the evolution of credibility at six central banks}

We present narratives on the evolution of credibility of six central banks: three major advanced countries (the United Kingdom, Germany and the United States) and three Latin American countries (Chile, Colombia and Mexico). Following each narrative we show a figure with the observed inflation rate and expected inflation. It is measured by mean forecasts from three different models as developed in Bordo 
and Siklos (2014). For the Latin American countries we were unable to generate a comparable measure of expected inflation owing to some data limitations.

\subsection{United Kingdom}

The Bank of England was founded in 1694. It was a private chartered joint stock bank with a public function. It was designed to aid the British government in placing its debt. In exchange for being the government's financier it was given the right to issue bank notes and to take on other private banking functions. Over time it evolved into a banker's bank, taking deposits from the nascent commercial banks because of its important position. The Bank's charter required that it keep its notes convertible into gold at the official price of $\mathrm{L} 3.17 \mathrm{~s} 9 \mathrm{~d}$ per ounce of gold. By maintaining gold convertibility, the Bank gained credibility early on.

The Bank had operational independence but not goal independence, i.e. its main goal was to stay on the gold standard but it had control of its main policy tool—Bank Rate (the discount rate)-- and the government could monitor its performance since its charter was subject to periodic renewal.

The gold standard rule that the Bank followed in the eighteenth and nineteenth centuries was a contingent rule, in the sense that in times of emergency, such as major wars, the Bank could request permission from the Treasury to temporarily suspend convertibility and issue inconvertible bank notes, as was indeed the case during the Napoleonic wars, during which the Bank suspended convertibility in 1797 and restored it after hostilities had ceased, in 1821. Inflation reached a peak of $10 \%$ per year in 1810 and then declined to its prewar level by the time of 
Resumption. These actions ensured the Bank's credibility (Bordo and Kydland 1995).

During the nineteenth century the Bank evolved into a lender of last resort in the face of banking panics. In many crises, beginning in 1825 and ending in the Overend Gurney crisis of 1866 the Bank lent too little and too late. By the Baring crisis of 1890 the Bank finally learned to follow Bagehot's (1873) Responsibility Doctrine to subsume its private interest to its public responsibility (Bordo 1990). This also enhanced its credibility.

During the heyday of the Classical gold standard 1880-1914 the Bank generally followed the "rules of the game" using its main policy tool, Bank rate, to speed up the adjustment to balance of payments disequilibria. On occasion, to make Bank Rate effective, the Bank used open market operations and gold devices. (Bordo 1981). Because of its credibility the Bank had considerable flexibility to achieve goals other than convertibility, i.e. to smooth interest rates, output and prices (Bordo and MacDonald 2005).

World War I in August 1914 led to de facto suspension of the gold standard but not de jure until 1918. The Bank of England became an engine of inflation by freely discounting short term Treasury bills at a low pegged interest rate to aid the Treasury in its war finance. For a year after hostilities ceased, prices kept rising, at close to $200 \%$ in total. The British monetary authorities expressed a strong interest in restoring the gold standard at the original parity as soon as possible in the Cunliffe report of 1918. Resumption would require politically unpopular deflation. The Bank engaged in tight money beginning in 1919 and the UK returned to gold at 
$\$ 4.866$ in April 1925. Many argue that sterling was overvalued by at least $10 \%$. This overvaluation in one of the key reserve currencies, along with other flaws, meant that the reestablished gold exchange standard would prove to be not as durable as the classical gold standard but it was as credible, at least until 1931 (Bordo and Macdonald (2002).

The gold exchange standard broke down in 1931 because of major flaws including maladjustment, illiquidity and lack of confidence. Under a heavy speculative attack in summer 1931 the UK left the gold standard. The UK's experience with deflation and depression was much less than other countries like the US that had continued to stay on gold (Eichengreen 1992). After Britain had left gold, devalued and floated sterling the Bank embarked on a reflationary policy through the 1930s.

During the Second World War the Bank again became an engine of inflation and subsumed its independence to the Treasury. This led to a period of high inflation which carried through into the 1950s. The Bank was nationalized in 1945 and officially lost whatever independence it had. The UK became part of the Bretton Woods system in 1946 but did not achieve current account convertibility until December 1958. The 1950s and 60s was a period of stop- go monetary policy. Like in the interwar, sterling was overvalued and the UK ran persistent balance of payments deficits, often culminating in currency crises, ended by international rescues. Once the balance of payment constraint was relaxed the monetary and fiscal authorities would stimulate the economy leading to a run up of prices and another sterling crisis. The stop- go pattern ended after the Devaluation of 1967 which also ended sterling's role as a reserve currency (Bordo 1993). 
During the 1950 s and 60 s it was widely believed in the UK that monetary policy was impotent as described in The Radcliffe Committee Report of 1960. Radcliffe advocated the use of credit allocation policy and fiscal policy rather than monetary policy to maintain full employment (Capie 2010).

After the Bretton Woods system broke down between 1971 and 1973, sterling floated and without an external nominal anchor the UK entered the Great Inflation reaching inflation rates over $20 \%$ and a total loss of credibility in the late 1970 s. The Treasury, which controlled monetary policy, believed inflation was caused by nonmonetary, cost push forces and advocated the use of incomes policies rather than tight money to allay it (Dicicio and Nelson 2013).

The high inflation rate produced a major currency crisis necessitating an IMF rescue in 1976. The inflation spiral was finally ended in 1980 when Margaret Thatcher came to power. Thatcher and her advisor Alan Walters adopted monetarist orthodoxy and greatly reduced money growth, liberalized the financial system, and removed capital controls. This led to a serious recession in $1980-81$ but by the mid1980s the policy broke the back of inflation and inflation expectations as was occurring at the same time in the U.S. Like the US, this was the beginning of a period of low inflation, later called the Great Moderation. However unlike the Volcker Fed, the Bank of England did not have independence. That did not occur until 1998 when it achieved operational but not goal independence from the Treasury. The UK Treasury and the Bank in the 1980s and 1990s had the primary goal of low inflation and, following New Zealand's example, began formal inflation targeting in 1992. 
Since then the UK has generally had low inflation and anchored inflationary expectations.

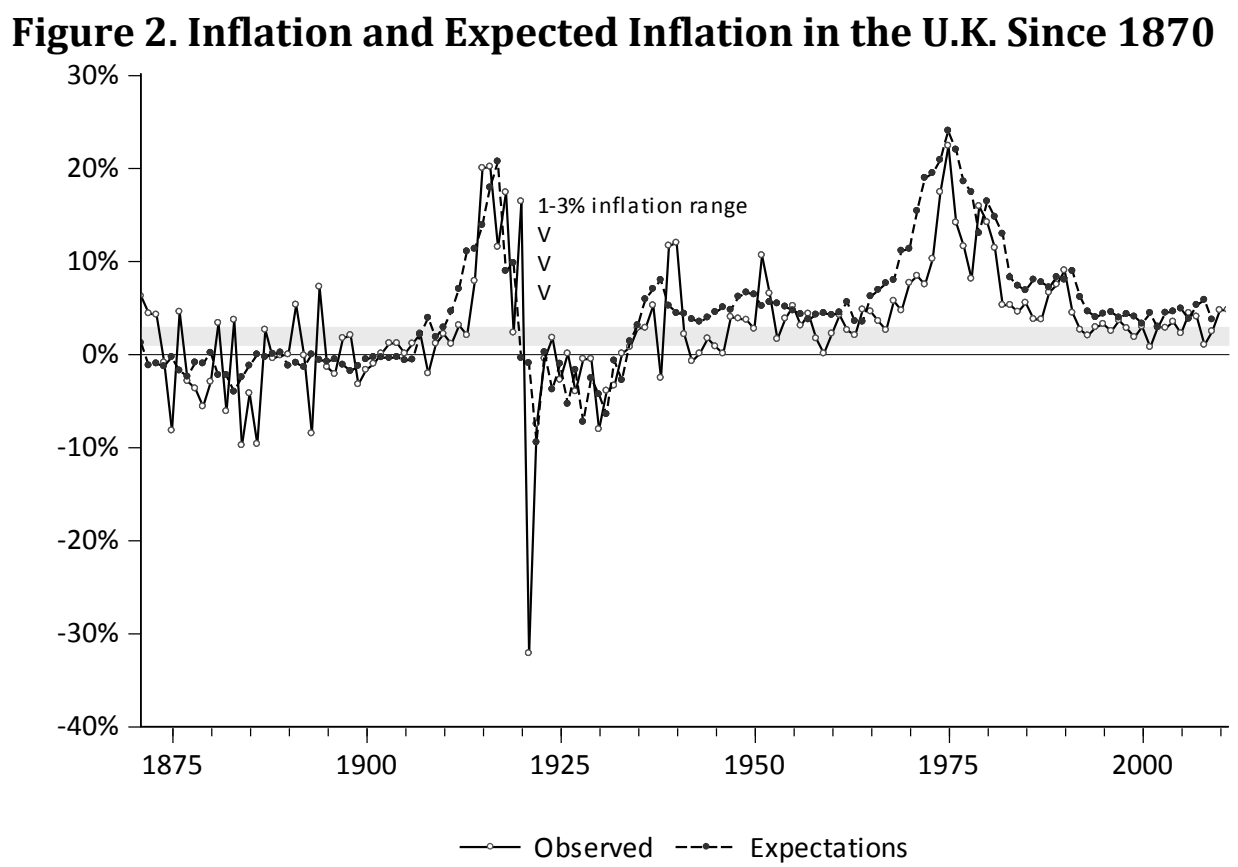

Note: Inflation in consumer prices. See Bordo and Siklos (2014) for details about the estimation of expectations. The 1-3\% band shown throughout is for reference purposes only as formal inflation targeting dates from the late 1990s only.

\subsection{Germany}

The Reichsbank was founded in 1876 shortly after the Franco Prussian War, German reunification and Germany's joining the gold standard. The Reichsbank had private ownership but public management (Singleton 2008). It had operational independence within the confines of the gold standard. It was established to unify the currency, preserve gold convertibility, act as a central bank (to use its discount rate to provide liquidity for the money market based on bankers acceptances) and be a lender of last resort.

The Reichsbank was successful in maintaining the gold standard until World War I and it generally followed the rules of the game (Bordo and Eschweiler 1994). It also 
was a successful lender of last resort in the financial crises of 1901 and 1907. Thus the Reichsbank had considerable credibility and the German price level was well anchored.

Germany abandoned gold convertibility at the start of World War I and the Reichsbank became part of the government. It freely discounted government paper at a low interest rate peg, becoming a major engine of inflation. After defeat in 1918 the Reichsbank under its President Havenstein continued to be an engine of inflation which became hyperinflation by 1923 . The basic problem was an impossible fiscal impasse in which the Weimar government could not raise the tax revenues needed to pay for reparations and postwar reconstruction and other expenses so it resorted to the printing press. By 1923 the Reichsbank lost its credibility and the German mark became worthless. In the Currency Reform of 1923, Havenstein was succeeded by Hjalmar Schacht as President of the Reichsbank. In 1924 the Reichsmark was created, fiscal balance was restored with the aid of massive foreign loans, and the currency was pegged again to gold at a vastly devalued rate from its prewar parity. For 7 years Germany had price stability and credibility was restored (Bordo and MacDonald 2002). Schacht cooperated with Montagu Norman (Governor of the Bank of England), Emile Moreau (Governor of the Banque de France, and Benjamin Strong (Governor of the Federal Reserve Bank of New York) to maintain the Gold Exchange Standard (Ahmed 2010).

The Great Depression, which began in the US, spread quickly to Germany, which had borrowed heavily in the US and quickly lost access to the foreign capital inflows needed to service reparations. Germany had as serious a contraction and deflation 
as the US. The Reichsbank, following gold standard orthodoxy maintained a tight monetary policy making things worse (Eichengreen 1992). The Creditanstalt crisis in Vienna in May 1931, which led to a bailout by the Austrian National Bank and government, provoked a run on the Austrian schilling, a freeze on foreign deposits and the imposition of exchange controls (which de facto removed Austria from the gold standard).The banking crisis then spread to Germany in July 1931. The German government bailed out most of the commercial banks, froze foreign deposits and like Austria imposed exchange controls and de facto left gold. The German financial crisis and the Depression contributed greatly to the victory of National Socialism in the elections of 1933. Under Hitler, the Reichsbank became the government's bank and greatly helped finance rearmament and then World War II. The Bank instituted a panoply of internal and external controls. World War II led to high (and suppressed) inflation which continued after defeat.

After the war, the allies established the Deutscher Lander Bank (BdL), which like the early Federal Reserve was a loose federation of regional banks coordinated by a Board. The BdL was dedicated to preserving the value of the currency (both external and internal). It was made independent from the Federal Government. The Currency Reform of 1948 ended inflation and created a new currency, the Deutschemark. The BdL based on the stability culture of postwar Germany focused primarily on price stability and led Germany into a pattern of low inflation. (Beyer et al 2013).

The BdL was superseded by the Deutsche Bundesbank (DBB), established by the Federal Government of Germany in 1958. Like its predecessor it was dedicated overall to maintaining the value of the Deutsche Mark (DM). Under the Bretton 
Woods System the DBB faced a conflict between maintaining the dollar peg and internal price level stability since under a pegged exchange rate the money supply becomes endogenous. In the Bretton Woods era, West Germany, because of its rapid productivity growth and high growth rate, kept running current account surpluses which would lead to dollar inflows, and unless they were sterilized would lead to faster money growth and inflation. In response to the inflationary pressure Germany imposed controls on capital inflows and revalued the DM in 1961 and 1969 (Bordo 1993). Once the Bretton Woods system broke down between 1971 and 1973, The DBB began to focus on maintaining the internal value of the DM. Its attempts to maintain price stability were not successful with the first oil price shock in 1973 when inflation rose to $8 \%$ per year.

In 1974 the DBB adopted monetary growth targeting to gradually reduce inflation. The monetary targeting framework was supposed to both control inflation and influence inflation expectations. The DBB roughly followed monetarist doctrine in targeting Central Bank Money (similar to M3) and gradually reducing its targets, but it often missed its targets. According to Beyer, et al 2013) although the DBB missed its targets, it always explained the misses and hence followed pragmatic monetarism. The DBB's policy did succeed in making Germany's inflation rate (along with Switzerland) consistently the lowest among the advanced countries during the Great Inflation. The experience of low inflation and the fact that Germany did not accommodate the second oil price shock in 1978-79 gave the DBB very high credibility before the 1980s, in sharp contrast to the US and UK .The DBB kept following money targeting until the advent of the Euro in 1999. The DBBs monetary 
targeting approach and its credibility for low inflation were incorporated into the European Central Bank as its two pillar strategy.

Figure 3. Inflation and Expected Inflation in Germany Since 1871 OBSERVED and EXPECTED INFLATION: Germany

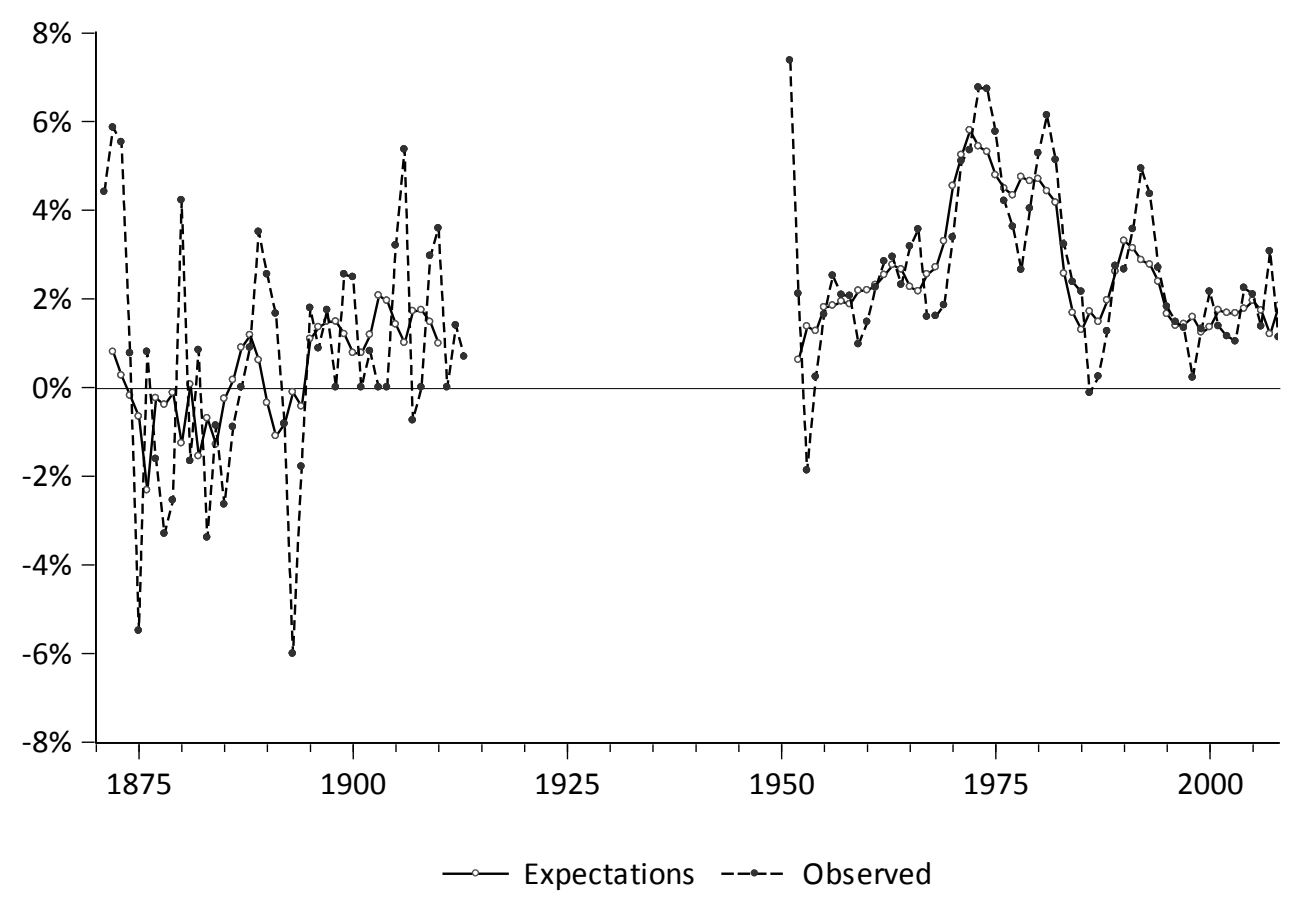

Note: the gap in the series is due to World Wars I and II and the German hyperinflation of 1921-24. See Bordo and Siklos (2014) for details about the estimation of expectations.

\subsection{United States}

The Federal Reserve was established in 1913 to act as a lender of last resort and to preserve the gold standard. The U.S. hadn't had a central bank since the demise of the Second Bank of the United States in 1836. The U.S. had been on a specie standard (bimetallism before 1873, gold thereafter) standard throughout the nineteenth century with the exception of the Greenback paper money floating 
exchange rate episode from 1862 to 1879 . Under the gold standard, the U.S. had long-run price stability (alternating periods of rising and falling prices driven by the vagaries of the gold standard). The U.S's inflation credibility was nearly as good (with the exception of the Free Silver threat in the early 1990s) as the advanced countries of Europe which had central banks (seen in long-term interest rate spreads on gold bonds Bordo and Rockoff 1996). The main problem in the U.S. was financial instability manifest in frequent banking panics $(1837,1857,1873,1884$, 1993 and 1907) in the absence of a true lender of last resort.

The panic of 1907 was the event that broke the camel's back leading to the movement for monetary reform. The prototype for a US central bank was contained in the Warburg Plan of 1910-a loose federal system of regional central banks, each modeled after the Reichsbank in Germany to be coordinated by a Board in Washington. The Reserve banks would use their discount rates to freely accommodate banker's acceptances and act as a lender of last resort. The Federal Reserve System founded in 1913 took on many of the aspects of the original Warburg Plan with a much stronger federal government presence in the Federal Reserve Board (Bordo and Wheelock 2013).

World War I broke out just before the Fed was to open its doors leaving the U.S. as one of the few countries still on the gold standard (with the exception of a gold embargo 1917-1919). Gold inflows from the belligerents' purchases of US goods fueled inflation which was aggravated after the US joined the war in April 1917 when the Fed began financing the US Treasury's bond issues at a low pegged 
interest rate. By wars end the US price level had increased close to $100 \%$, (the lowest rate of the belligerents).

After the war the Fed began sharply raising its discount rate in 1919 after its gold reserves were threatened by continued high inflation. This led to a serious but short-lived recession and deflation from 1920-21. The period 1921 to 1929 was characterized by mild deflation and rapid economic growth punctuated by two mild recessions. Friedman and Schwartz (1963) and Meltzer (2003) gave the Fed high marks for attenuating the recessions, preventing banking panics and preserving price stability. The 1920s can be regarded as a period of high Federal Reserve credibility.

The Great Contraction of $1929-33$ can be attributed to several failures of US monetary policy. These include loose monetary policy in 1927 to aid the UK in its struggles to stay on the gold exchange standard which may have fueled asset booms in housing and later stocks (Bordo and Landon Lane 2013); Fed tightening in early 1928 to stem the stock market boom which contributed to a downturn in August 1929 followed by the stock market crash of October (Siklos 2008); c) the failure to act as lender of last resort and prevent four banking panics from October 1930 to March 1933. This policy failure contributed greatly to an unprecedented collapse in money supply, real output and prices. The massive (over 30\%) decline in prices led to a major loss of credibility.

The Great Contraction ended in March 1933 and recovery followed quickly after the incoming Roosevelt administration declared a one week banking holiday, exited the U.S. from the gold standard, engaged in massive gold (and silver) purchases and 
then devalued the dollar by $60 \%$ a year later. Prices and real output rebounded rapidly from 1933 to 1937 , interrupted by a sharp recession in 1937-38 which Friedman and Schwartz (1963) attribute to the Fed's doubling of reserve requirements in 1936 to absorb banks excess reserves and the Treasury's policy of sterilization of gold inflows.

The Federal Reserve system was reorganized in 1933 and 1935 and the Board of Governors was given enhanced powers. However during the 1930s the Fed did not play a very active role in monetary policy which had been taken over by the Treasury. From the 1930s onward the Fed began following a low interest rate policy to accommodate the Treasury's fiscal policies (Meltzer 2003). During World War II the Fed again became an engine of inflation although prices did not rise as much as in World War I because of extensive price controls. The interest rate pegs were kept after World War II and in the 1940s inflation became a problem leading the Fed to campaign to regain its independence to raise its policy rates. This was achieved after a considerable struggle with the Treasury and the Administration in the Federal Reserve Treasury Accord of 1951. The Fed tightened policy in the early 50s and restored price stability. Under Chairman Martin the Fed followed a policy of low inflation and the economy performed well through much of the 1950s and early 60s. During this period the US performed well in keeping inflation low as the provider of the key currency of the Bretton Woods System.

The era of credible inflation ended after 1965 when, under pressure from the Johnson administration the Fed began accommodating expansionary fiscal policies to support the Vietnam War and the Great Society. This led to the beginning of the 
Great Inflation (1965 to 1982). The Fed also began following Keynesian doctrine (the Phillips Curve tradeoff) and made achieving full employment (at the expense of inflation) its paramount policy goal. As inflation and inflationary pressures mounted in the 1970s, several attempts by the Burns led FOMC to reduce inflation faltered when it led to recession and rising unemployment, leading to a ratcheting up in inflation and inflation expectations (Bordo and Orphanides 2013). Accommodation of two oil price shocks also contributed to the run up in inflation. By the late 1970s the Fed had lost considerable credibility for low inflation. This culminated in a run on the dollar in 1978.

In 1979 President Carter appointed Paul Volcker as Chairman of the Fed with a mandate to end inflation. Volcker followed a monetarist policy strategy, targeting non borrowed reserves and letting interest rates be determined by market forces. Interest rates rose to close to $20 \%$ by 1980 . Volcker's tight money policy triggered a sharp recession in 1979-80. It was aggravated by the Carter administration imposing controls on credit card expenditures. In reaction the Fed loosened policy in late 1980. Immediately inflation and inflationary expectations rebounded. Several months later, with the support of the newly elected President Reagan, Volcker reapplied the monetary brakes triggering a second recession and this time it did not stop tightening despite the unemployment rate rising well above $10 \%$ until inflation and inflation expectations abated in 1982. The Fed's credibility suffered after the first recession and only was regained after the second (more severe) Fed induced downturn (Bordo, Erceg, Levin and Michaels 2007). 
The Fed reestablished its credibility for low inflation by the mid 1980s seen in declines in nominal interest rates, in the TIPS spread and in various measures of inflation expectations. The 20 year episode of good economic performance is referred to as the Great Moderation. Alan Greenspan took over as Fed Chairman in 1987. He quickly prevented a major stock market crash from leading to a banking crisis and then followed the Volcker approach to maintaining credibility for low inflation. This policy was put to the test by the inflation scare of 1994 when rising long-term bond yields signaled a run up in inflationary expectations. The Fed tightened sharply, raising real interest rates. And then when inflation expectations eased, the Fed loosened, preventing a recession. (Goodfriend 1993).

The Great Moderation ended with the Financial Crisis of 2007-2008. Loose Federal Reserve policy of keeping the Federal Funds rate well below the Taylor rule rate from 2003 to 2005, in an attempt to head off potential deflation, added fuel to a burgeoning real estate boom which burst in 2006 triggering the crisis. (Taylor 2007, Bordo and Landon Lane 2013b). The Fed reacted to the crisis by following aggressive monetary policy of cutting the FFR in the fall of 2007, opening the discount window to many nonbank financial institutions and non traditional markets and by a controversial bailout policy in fall 2008 (bailing out Bear Stearns, AIG and the GSEs ) and letting Lehman fail in October. That action triggered a global financial crisis. The Fed reacted to the panic by cutting the FFR to zero and instituting several unorthodox discount window facilities. These policies combined with the Treasury's TARP plan, stress tests and an inter central bank swap arrangement ended the crisis. By late fall 2008 the Fed's policy rate had hit the zero 
lower bound and with the recession still on going, the Fed instituted its Quantitative Easing policy (QE1) -- the purchase of long term Treasuries and mortgage backed securities. This unconventional policy was followed in the next 4 years by three other packages in the face of an unprecedented (after a financial crisis) slow recovery (Bordo and Haubrich 2012). These policies have quadrupled the Fed's balance sheet, and many argue could lead to a future inflation policy. The Fed may have lost considerable credibility with the crisis and time will tell if it regains its credibility for low inflation by how it exits from QE.

\section{Figure 4. Inflation and Expected Inflation in the U.S. Since the Fed's Creation}

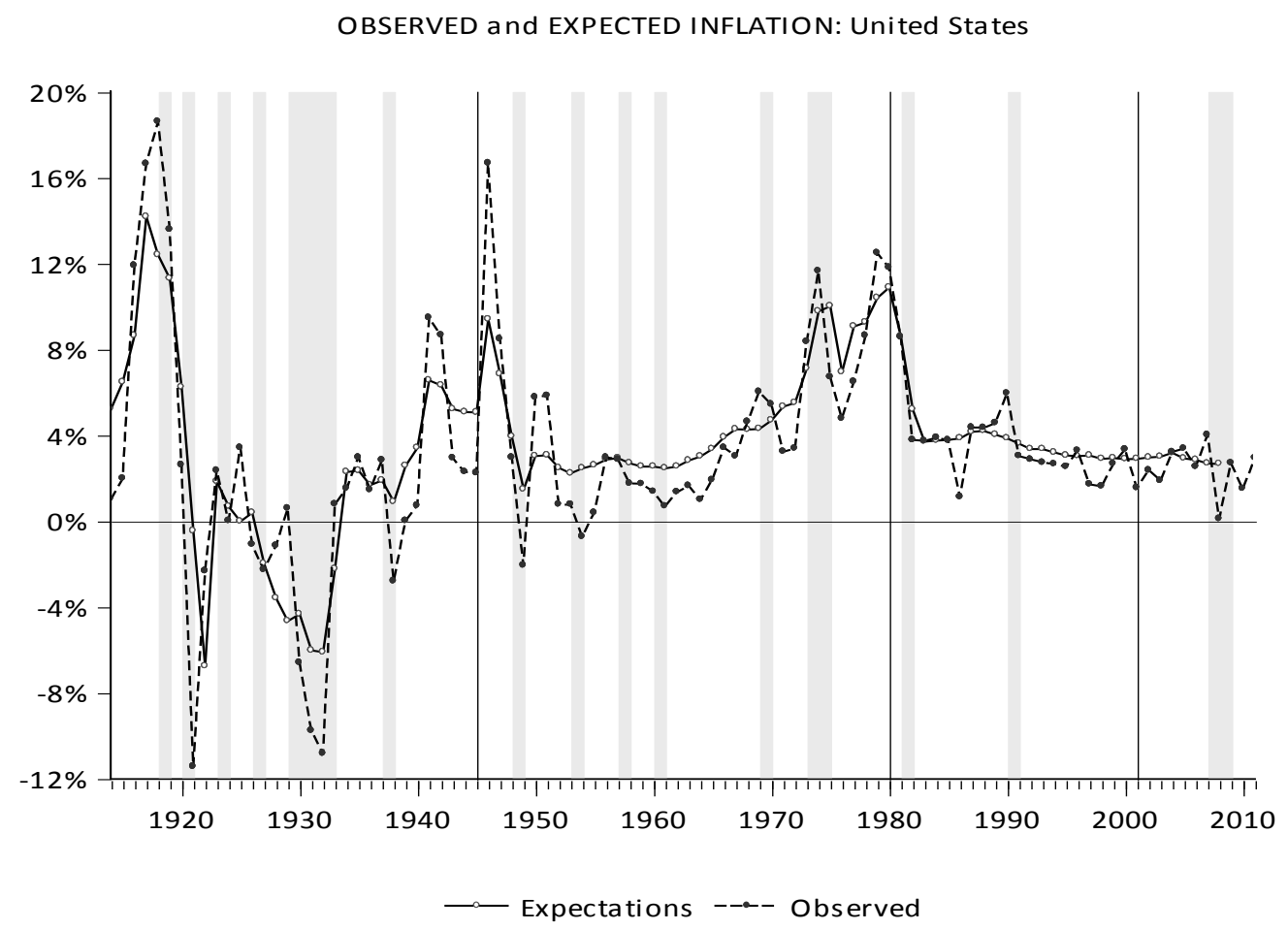

NOTE: Vertical lines and shaded areas are NBER recession dates. See Bordo and Siklos (2014) for details about the estimation of expectations. 


\subsection{Chile $^{4}$}

As was the case with other Latin American countries in the nineteenth century Chile did not have a central bank. It was on a bimetallic standard from 1818 to 1851 . It made a technical change in the mint ratio and stayed on bimetallism until 1861 when it suspended. It resumed in 1870 , but by the end of 1874 with the fall in the price of silver, it was on a de facto silver standard. Bad harvests during the next three years, and accompanying balance of deficits, were followed by bank runs in 1878. The authorities made bank notes inconvertible in July 1878 . For the next 17 years, Chile remained on a paper standard. In 1879 the War of the Pacific began, with Chile opposing Bolivia and Peru, and ended in 1883 with Chile the victor. The war was financed by government note issues. Declining prices of nitrate and copper in the world market led to depreciation of the Chilean peso from 1883 to 1899 (Bordo and Schwartz 1999).

The first attempt to return to a metallic standard was made in 1887 , but it failed. In the next four years bank notes and government notes rose considerably. An eight month Civil War from January to August 1891 resulted in further monetary expansion and exchange rate depreciation. A second Conversion Law in November 1892 was strictly implemented and the exchange rate appreciated, but again the government responded to political discontent by issuing notes. The exchange rate thereupon depreciated. A new Conversion Law in February 1895 established a mechanism to accumulate a gold reserve and have notes backed by gold or bonds to be acceptable for taxes. This reduced the money supply. Following rumors of war

\footnotetext{
${ }^{4}$ Much of this discussion was developed by Cesar Tamayo of the IADB.
} 
with Argentina and a run on banks in July 1898 led to the end of convertibility until 1925, when it again devalued, and in 1931 it abandoned the gold standard.

Against this checkered history there were several attempts to set up a central bank. The Central Bank of Chile (BCC) was finally created in 1925 following a mission by Edwin Kemmerer from the United States ${ }^{5}$. The BCC was conceived as a private institution with the government as a minority shareholder. It was granted a monopoly of the currency issue and as mentioned above convertibility was restored. Limits were set to credit the BCC could extend to the government to give it a modicum of independence. With the advent of the Great Depression, Chile abandoned the gold standard. By the 1930s continuous expansion of central bank credit to the government and the private sector led to a rapid acceleration of inflation which reached $30 \%$ by 1946 . Central bank credibility was greatly weakened. During the 1950s inflation in Chile reached $80 \%$.

A first attempt to strengthen central bank credibility was a stabilization program (1959 to 1962) which aimed to eliminate central bank financing of government spending and restoring a par value of the peso with the US dollar. The policy had very limited and temporary success and inflation resumed and the dollar peg was abandoned in 1962 (Corbo and Hernandez 2005).

\footnotetext{
${ }^{5}$ Kemmerer was a reputed American economist who spent most of his career at Princeton University. Although he held various posts within the U.S. government (including Trade Commissioner for South America), he is best known as the "Money Doctor" for his role as advisor to many developing countries in monetary and financial matters. He led special commissions that eventually resulted in the creation of many central banks, starting with his visit to Mexico in 1917 and followed by Guatemala (1919), Colombia (1923), Chile (1925), Poland (1926), Ecuador (1927), Bolivia (1927), China (1929) and Peru (1931), among many others (for more details see Howard et. al (1946)).
} 
The problem of central bank financing of government expenditures was difficult to overcome and the BCC continued to extend credit against various types of government securities (Bianchi 2009). A second attempt to stabilize the economy was made in the mid -1960s when the BCC was relieved of its commercial banking operations and a crawling peg exchange rate was adopted. The 1960s and 1970s were years with massive fiscal deficits fully financed by the BCC, resulting in money growth of $66 \%$ by 1971 . In 1973, under the Allende government, the fiscal deficit reached $30 \%$ of GDP and inflation topped $600 \%$. By then BCC had lost whatever was left of its reputation.

The Pinochet regime imposed a severe contractionary policy in 1974-75 which turned the fiscal deficit into a $4 \%$ surplus. Inflation fell to double digits. Thereafter fiscal imbalances have remained low. This development paved the way for Chile's transit towards a moderate and later a low inflation country (Sargent, Williams and Zha 2009). In 1979 the authorities decided to use the exchange rate as the nominal anchor for the disinflation process, first under a crawling peg with progressively decreasing increments (the tablita) and finally under a fixed parity.

Chile's second attempt to adopt an exchange rate stabilization program was also constrained, this time by external factors. After some years of sustained growth and relative macroeconomic stability, the monetary and fiscal policy mistakes of the sixties and seventies were replaced by concerns over the external accounts. As foreign trade was basically reinstated toward the end of the seventies, and as the world economy poured capital toward developing countries, current account deficits soared, reaching $10 \%$ of GDP in 1981. With alarming levels of foreign 
indebtedness, the Chilean economy then had to face rising costs of servicing its debt (due to a monetary contraction in the U.S.), and by early 1982 a severe balance of payments crisis dragged Chile into its most severe post-1929 economic recession. During 1982-83, virtually the entire financial system collapsed and the government defaulted on its foreign debt; the cost of the crisis has been estimated to be close to 35\% of GDP (Sanhueza 2001). After the fixed exchange rate regime collapsed in early 1982, the central bank aimed for a crawling peg regime and later introduced a narrow band in an effort to gain some flexibility in the day-to-day management of currency and reserves. As with previous attempts to find a nominal anchor, the credibility in the central bank exchange rate policy was undermined by the subsequent devaluations of 1984 and 1985 (De Gregorio 1999).

The 1980s financial collapse required massive government intervention which put an end to the short period of fiscal surpluses, and in 1983 the government deficit was again close to 3\% of GDP (Braun-Llona et al. 1998). This was also the time in which the central bank became involved with quasi-fiscal operations since the reconstruction of the financial system required central bank losses and debt issuance. Recent studies have shown that the persistent negative net worth of the BCC can be traced back to role of the central bank during this crisis (Restrepo, Salomo and Valdes 2008). Faced with large negative shocks, the undercapitalization of the central bank can threaten either its independence (it would require emergency recapitalization by the executive) or directly the credibility of its antiinflationary policies (the central bank could be tempted to increase its revenue from seigniorage) or, more likely, both. 
By the mid-1980s, the central bank was already moving toward price-based instruments and away from the quantity-based instruments (e.g., "encaje"), and near the end of the decade, the exchange rate band was widened from $+/-2 \%$ to $+/-5 \%$. However, the high degree of inflation inertia and indexation forced BCC to use the real interest rate as its main policy tool (Morande and Schmidt-Hebbel 2001). It was also toward the end of the eighties, that the central bank was granted full goal and instrument independence from the government with the constitutional amendment of 1989. The BCC was then charged with the stability of the currency and the payments system. The choice of nominal anchor was the inflation rate itself, leaving Chile at the vanguard of the inflation targeting strategy (second after New Zealand). The first inflation target was announced in 1990 to be met at the end of 1991 defined as a range of between $15 \%$ and $20 \%$. In time, the exchange rate regime became increasingly flexible and the exchange rate band became wide enough so as to accommodate external shocks to a certain extent. However, in the first years under the IT regime, the credibility of the BCC policies was less than perfect. A combination of an incomplete adoption of the IT framework and the effective pursuit of two goals (inflation and the exchange rate band) with one instrument (the interest rate) may be responsible for this initial lack of credibility. Evidence of this can be found in the exchange rate-to-inflation pass-through coefficient, which remained high for the most part of the 1990s (Garcia and Restrepo 2001; Bravo and Garcia 2002). Thus, throughout the first decade of BCC operation, monetary policy was conditioned by the central bank's intervention in the foreign exchange market; a number of discretionary changes in the width of the exchange rate band were 
necessary while the capital inflows surge of the early 1990s resulted in a sharp real appreciation and a four-fold increase in central bank's foreign reserves between 1990 and 1994 (see Calvo, Leiderman and Reinhart, 1996). It should be stressed, however, that such strong appreciation of the peso actually contributed to the initial success of BCC in bringing down inflation almost monotonically throughout the 1990s (for evidence, see, e.g., Corbo, 1998).

The Asian crisis and the subsequent Russian default brought substantial turmoil to Latin American countries and the Chilean peso depreciated significantly (30\% between 1997 and 1999). In September 1999, the exchange rate band was finally dismantled and the peso was allowed to float. With this major policy shift began what De Gregorio, Tokman and Valdes (2005) call Chile's experience with a fullfledged IT strategy. This new policy environment included a public announcement of a long term inflation target range - between $2 \%$ and $4 \%-$ and foreign exchange intervention only under extraordinary circumstances (to be materialized in 2001 and 2002).

By 2001, and due to the systematic fall in inflation and indexation, the BCC was in a position to begin using the nominal interest rate as the main policy instrument. More formal measures of success and credibility of the central bank's strategy can be found as well. Landerretche, Morande, and Schmidt-Hebbel (1999) show that one-year-ahead (model-based) inflation forecasts made before the announcement of the inflation target each year have systematically overstated actual inflation. In other words, the announcement of a target has helped correct inflation forecasts which in turn contributes to anchoring actual inflation. 
Another strategy to assess the credibility of the BCC is followed by Cespedes and Soto $(2005,2007)$. These authors formally show that when credibility is low, the policy tradeoffs are more pronounced (e.g., higher "sacrifice ratio") and the central bank would be less aggressive in implementing its monetary policy in order to avoid large output losses. In the case of Chile, these papers provide evidence that the monetary policy rule has become more forward-looking in terms of inflation and more aggressive in fighting deviations of inflation from the target. Inflation expectations as measured by survey data further reinforce this idea that BCC has been building credibility during the two decades under an IT regime. ${ }^{6}$ In fact, until 2002, expected inflation was systematically above the midpoint of the target (except in 1999) but fallen below the midpoint of the target ever since (see the figure below). Cespedes and Soto (2007) also point out the market for nominal instruments, which had existed in Chile for decades, only began flourishing at the turn of the century once the central bank was perceived to have inflation under control and started using the nominal interest rate as its main instrument.

\footnotetext{
${ }^{6}$ Landerretche, Corbo and Schmidt-Hebbel (2001) offer additional evidence that this gradualism toward a low stationary inflation rate has served the Chilean economy well.
} 
Figure 5. Inflation in Chile

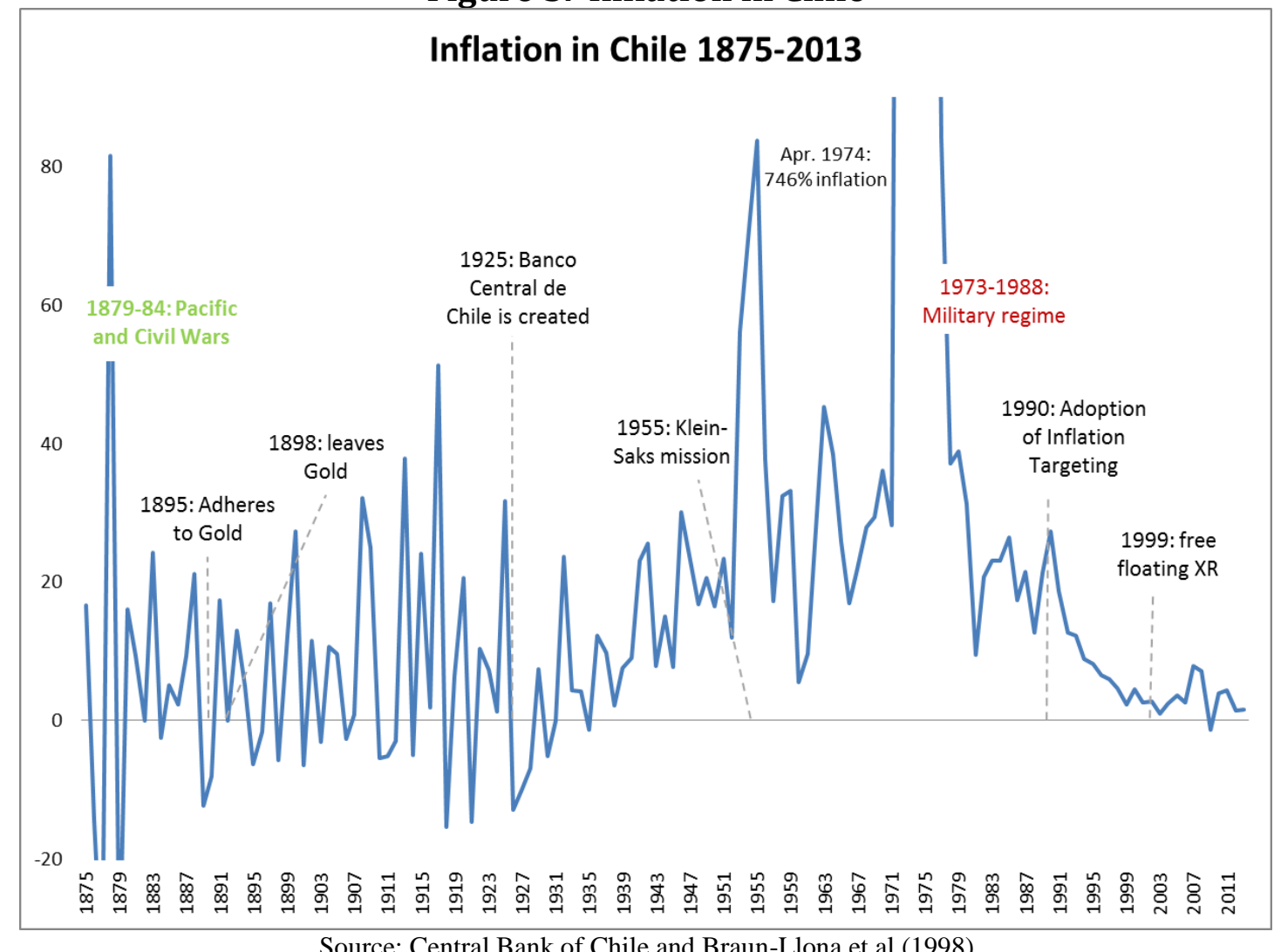

Source: Central Bank of Chile and Braun-Llona et al (1998) 
Figure 6. Inflation targets in Chile

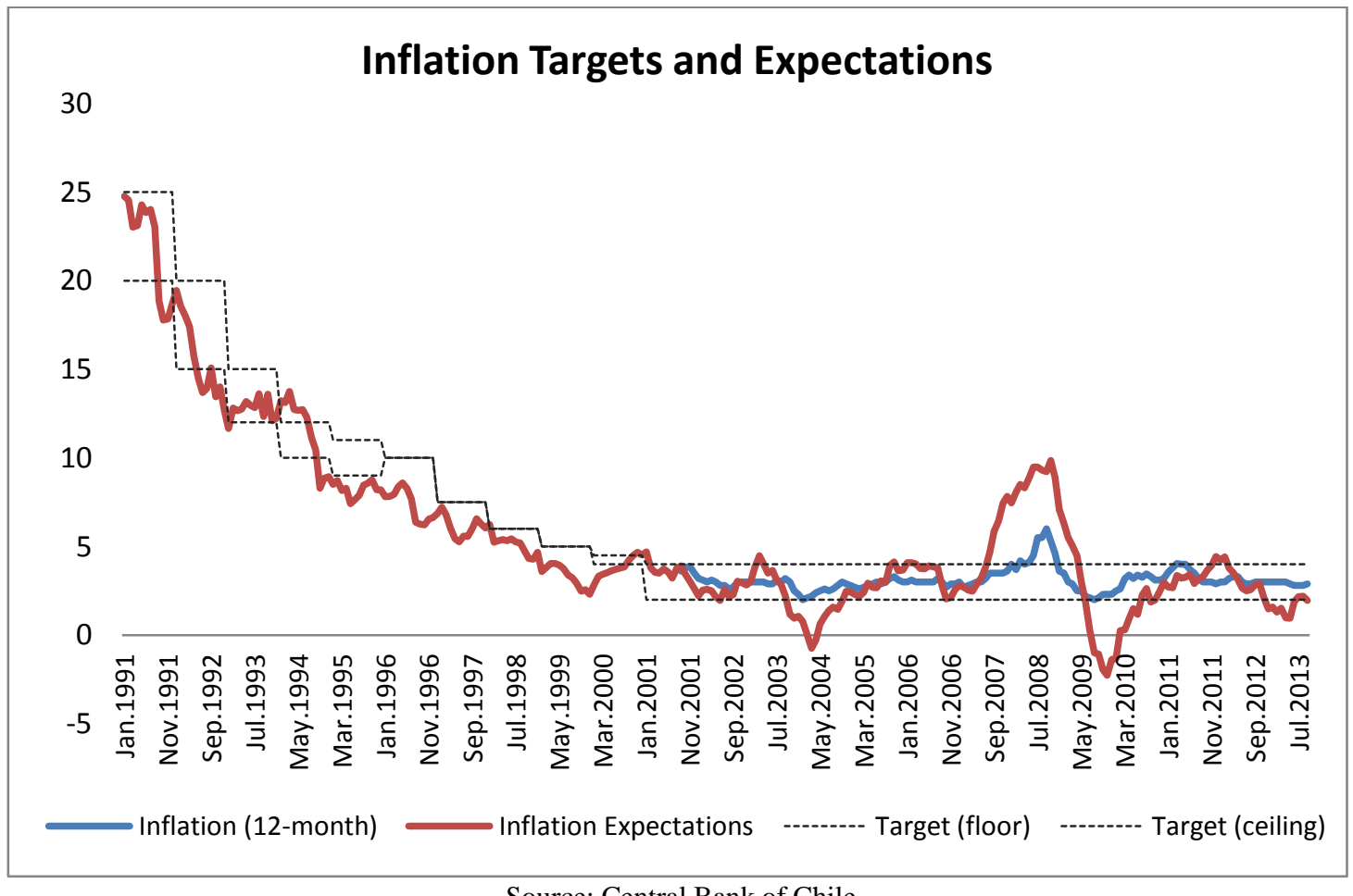

Source: Central Bank of Chile

\subsection{Colombia ${ }^{7}$}

The history of monetary policy in Colombia shares many features with that of Chile. During the 19th century, currency issuance was heavily dependent upon the fiscal stance; the war of independence as well as civil conflicts meant that coinage constantly varied in terms of weight and quality, bringing about occasional monetary instability.

As in Mexico, a strong system of free banking -in which national, state and privately issued bills coexisted- pre-dated the creation of a monetary authority (1863-1886). The Treasury was the single issuer of government notes until 1880 when Banco Nacional was created to operate as the government's bank and with the purpose of

\footnotetext{
${ }^{7}$ Much of this section is drawn from work by Cesar Tamayo at the IADB
} 
issuing national currency. However, it was the persistence of fiscal deficits and in particular the civil war of 1885 which triggered the unification of the monetary system and greatly undermined the free banking movement. In a clear effort to appropriate seigniorage revenues and ensure government access to foreign capital, notes issued by Banco Nacional became in 1885 the only legal tender and all other monetary standards were removed (Meisel, 1992). Although Banco Nacional was dismantled in 1894, its non-convertible bills would circulate as medium of exchange and unit of account until 1905.

The final decade of the 19th century was plagued with political turmoil and another civil war erupted in 1899. The conflict required a significant increase in government spending and led to unprecedented levels of paper money issuance. Such uncontrolled monetary expansion brought about the largest exchange rate devaluation and inflation rate in Colombian history. Toward the end of the conflict, the country saw the first systematic effort to enhance credibility in the monetary strategy when the government finally acknowledged the need to ensure consistency between monetary and fiscal policies (Lopez 1990).

Unsuccessful attempts to return to the gold standard characterized the first years of the 20th century. In 1905 the credibility of the monetary strategy received another lift -at least a temporary one- with the creation of Central Bank of Colombia (CBC). The CBC was conceived as an autonomous bank (fully owned by the private sector) and was granted the monopoly of currency issuance. The Bank quickly moved toward a partially convertible system in a clear effort to reinstate some kind of gold standard orthodoxy. However, the many extra-monetary tasks and functions that 
were introduced into the Bank's charter, and the poor management of external surpluses eventually posed numerous constraints on the ability of $\mathrm{CBC}$ to exercise appropriate monetary control. In due course, paper money issuance was again on the rise and the CBC was liquidated by Congress in 1909.

The economic effects of the First World War and the ensuing economic crisis of the 1920s made it imperative that the government gained access to external funds. To secure the confidence -and loans- of U.S. banks, many Latin American countries would seek a "seal of approval" from international experts in financial matters and the Kemmerer missions came to being. Although proposals for the introduction of a single monetary authority were put forth prior to the Kemmerer Mission, in 1922 Congress explicitly instructed the government to promote the creation of a central bank and the "Money Doctor" was called upon.

The Kemmerer Mission in Colombia culminated in the creation of Banco de la Republica (BR), which was chartered in 1923 as a mixed entity where government ownership was expected not to surpass 50\%. Private banks and especially foreign ones (given the strong dependence on external credit) were expected to be represented within the remaining $50 \%$. The creation of BR was accompanied by substantial financial legislation which brought a definite end to the era of freebanking, and regulated the formation and operation of financial institutions.

From its inception, it was acknowledged that BR was to act not just as a government bank but also as the banker of banks and as the single issuer of legal tender that could oversee monetary stability. Moreover, a strong sense of independence was evident in the creation of the Bank with a Board of Directors as its sole ruling body 
that appointed the governor without government intervention. Unfortunately, as with most central banks at the time, BR would still act as the Government's lender. The return to full gold convertibility in 1923 helped tame the inflationary pressures that would come from excessive lending to the government. By the same token, however, the "pegged" exchange rate regime and its endogenous money supply limited the ability of the central bank to manage the surges in capital flows of the mid 1920s and the ensuing financial crisis of the 1930s. At any rate, following the events of 1929 and the early 1930s, and after a second Kemmerer Mission, BR reluctantly abandoned convertibility right after Britain left gold in 1931.

In the post-Depression years Colombia was forced to run trade and fiscal surpluses, which translated into a moderate growth of money creation and relatively low and stable inflation. However, Keynesian ideas soon overtook economic policymaking; by the mid-1940s the economy was again running large fiscal deficits and BR's functions were successively modified to allow for larger and more frequent loans to the executive branch (Lopez 1990). This deficit monetization along with the scarcity of several imported goods that followed the American involvement in World War II fueled price increases and inflation reached $20 \%$ in 1944.

After the unprecedented devaluation caused by the moratorium of 1935 , the real exchange rate appreciated systematically during the 1940 s, due to a combination of growing export revenues and rising domestic prices. The government grew increasingly worried about this trend and led the efforts to promote exports through an undervalued currency. However, the several decreed devaluations of the late 1940s and early 1950s, and the introduction of a multiple exchange rate system 
did little to prevent further real appreciation in the face of persistent inflationary pressures. In a desperate effort to control inflation, the government and the central bank urged the major commercial banks in 1950 to restrict new lending (a so-called “Gentlemen's Pact"); as a consequence, the money supply contracted for the first time since the Great Depression and inflation entered negative terrain for a brief period.

The real contraction caused by the "Pact" was substantial and compounded with the appreciation problems already faced by domestic firms. Eventually, BR was called upon to supply credit to various private initiatives for export promotion as well as agricultural, industrial and urban development, a strategy that continued to undermine the credibility and independence of the central bank. At the same time, the Bank was given little command over the various monetary control instruments, and it was only after the explicit recommendation of a mission of experts from the New York Federal Reserve (the "Grove Mission") that BR was allowed to set and modify the reserve requirement. The latter would remain the principal monetary policy instrument for the next thirty years (Sanchez et al. 2007).

The late 1950s and 1960s were characterized by persistent macroeconomic disequilibria reflecting falling coffee prices and recurrent fiscal deficits (with a short period of surpluses in 1957-60) that the central bank eventually financed with issuance. After a severe balance of payments crisis in 1957, the government devised a stabilization plan aimed at rebalancing the external accounts by controlling devaluation expectations and restricting imports. It was during this period of marked heterodox economic policymaking and growing state intervention in the 
economy that BR was stripped of its monetary control function. In 1963 a new agency -the "Junta Monetaria" or Monetary Board- was created for that purpose, this time with full government control. The Board was composed of several ministers and other officials appointed by the president and the governor of BR which thereafter merely oversaw the execution of the Board's decisions and issued currency accordingly.

The Government control of the central bank was completed in 1971 when the central government nationalized the Bank's capital. Many scholars of Colombian monetary history agree that the inflationary bias that plagued the conduct of monetary policy throughout most of the second half of the century can be traced back to the government takeover of the monetary control functions in the early 1960s (Carrasquilla 1996). Indeed, there would not be an autonomous monetary authority in Colombia for the following three decades.

Shortly after the Board was established, Colombia adopted a crawling peg regime and during the 1970s and 1980s exchange rate management and capital controls were the main concern of the monetary authorities. In fact, Echeverry (1996) shows that shocks to foreign exchange (FX) reserves were the major source of fluctuations in the money supply and inflation during this period. Moreover, he argues that the persistence of moderate inflation for more than two decades in Colombia resulted from timid policy responses to such shocks.

With the spread of the 1982 debt crisis, the Colombian government found it increasingly difficult to obtain external funds to tackle the ensuing domestic financial collapse. Thus, BR was called upon to fund the government once again, this 
time through various financial instruments including explicit guarantees to government liabilities and direct credit lines to the Treasury. By 1985, the total government financing provided by the central bank (through the various instruments) amounted $4.5 \%$ of GDP, comparable only with the $2.2 \%$ reached in 1932 in the aftermath of the Great Depression (Kalmanovitz and Avella 1998).

The roots of the IT strategy in Colombia can be traced back to 1991, when a new constitution was drafted reinstating BR as the sole authority in charge of monetary control. After almost three decades of government-run monetary policy, the constitution formally made BR an autonomous agency with full operational independence. This was arguably the single most important institutional change concerning economic policy of the second half of the 20th century. Furthermore, the new constitution explicitly mandated the now independent central bank with the primary goal of maintaining price stability.

Given the importance that the constitution attached to central bank independence, the structure and composition of BR's Board of Governors became an important institutional design issue. It was decided that the Board would consist of seven members, two of which would be the Bank governor and the minister of finance. The incumbent administration could appoint at most two of the remaining members, who could serve for four consecutive periods (if reappointed). As in the original charter of 1923, the governor would be appointed by the Board.

The first step towards enhancing the credibility of monetary policy was to announce an inflation target which the central bank did for the first time in 1991. The BR strategy was clearly one of gradual disinflation; the inflation target for the first two 
years was set at $22 \%$ and remained above $15 \%$ until 1999 . Among the reasons for this slow adjustment were the relatively low credibility in the policies of the newly independent BR (Gomez 2000), and the difficult transition toward an intermediate exchange rate regime that allowed for some moderate flexibility.

With the change in focus toward an inflation target as the nominal anchor, a higher degree of exchange rate flexibility was required in order to regain monetary control. However, after a quarter of a century under a crawling peg, political and institutional constraints to let the currency float were numerous (Urrutia et al. 2014). Accordingly, BR adopted a currency band with positive slope as the exchange rate regime. During these transition years, monetary bands were used as intermediate targets, although an interest rate range was also defined in addition to the currency band. Such multiplicity of intermediate targets sometimes made difficult the formation of inflation expectations and may have also contributed to the slow process of disinflation (Reveiz 2002).

With the financial turmoil of 1998 and 1999, the central bank had to intervene repeatedly in the foreign exchange market and the currency band was adjusted upwards twice while the band itself was widened once. Eventually, the central bank was forced to let the currency float amidst large capital outflows and the most severe economic recession that Colombia has experienced since the 1930s which in turn called for IMF assistance and the beginning of a stand-by program.

Once the currency was allowed to float, the last requirement for a full-fledged IT strategy -which BR announced in 2000- was met and the central bank was finally able to set its monetary policy stance by using a single instrument: the interest rate. 
Moreover, with the recession at the turn of the century inflation fell steeply down to a single digit and contributed to breaking inertia in both actual inflation and, more importantly, expectations. This in turn allowed BR to reduce its inflation target from $15 \%$ in 1999 to $10 \%$ in 2000 and 6\% in 2001. For the last five years (2009-2013) inflation has hovered around 3\%, at the center of the central bank's long term inflation target of $2 \%-4 \%$.

Although the first 20 years of the IT strategy in Colombia have been of relative success, an issue that deserves some discussion is related to the management of the exchange rate regime. As it happens, the central bank has engaged in several episodes of capital controls and direct FX market interventions, most of them associated with protracted periods of currency appreciation. Vargas (2005) points out that such interventions, especially when aimed at affecting the trend or level (rather than the volatility) of the exchange rate, have been problematic for BR for several reasons. First, by implicitly aiming at some exchange rate target, the central bank sends conflicting messages as to its true priorities in terms of inflation. This in turn makes the process of communicating policy -a cornerstone of the IT strategy (Bernanke and Mishkin 1997)- difficult. Moreover, repeated interventions have usually failed to revert the appreciation trend and instead have resulted in quasifiscal costs through the valuation of reserves. Finally, sterilizing FX interventions involves selling government securities which has the double effect of reducing the availability of these instruments for monetary control and pushing up the secondary market rates which in turn increases the cost of government financing. 
In a recent empirical assessment of the FX market interventions by the central bank, Urrutia et al. (2014) argue that the costs in terms of credibility of the IT strategy have been relatively mild so far. However, these authors also point out that the overall impact of exchange rate movements on aggregate economic activity are negligible and that, in any case, the attempts to manage the exchange rate have been largely unsuccessful. Hence, the motivation for such rather unconventional interventions seems to be rooted in the political economy constraints faced by the central bank. This is an issue that remains unresolved since the unbalancing effect brought about by the introduction of presidential reelection is yet to be addressed.

Figure 7. Inflation in Colombia

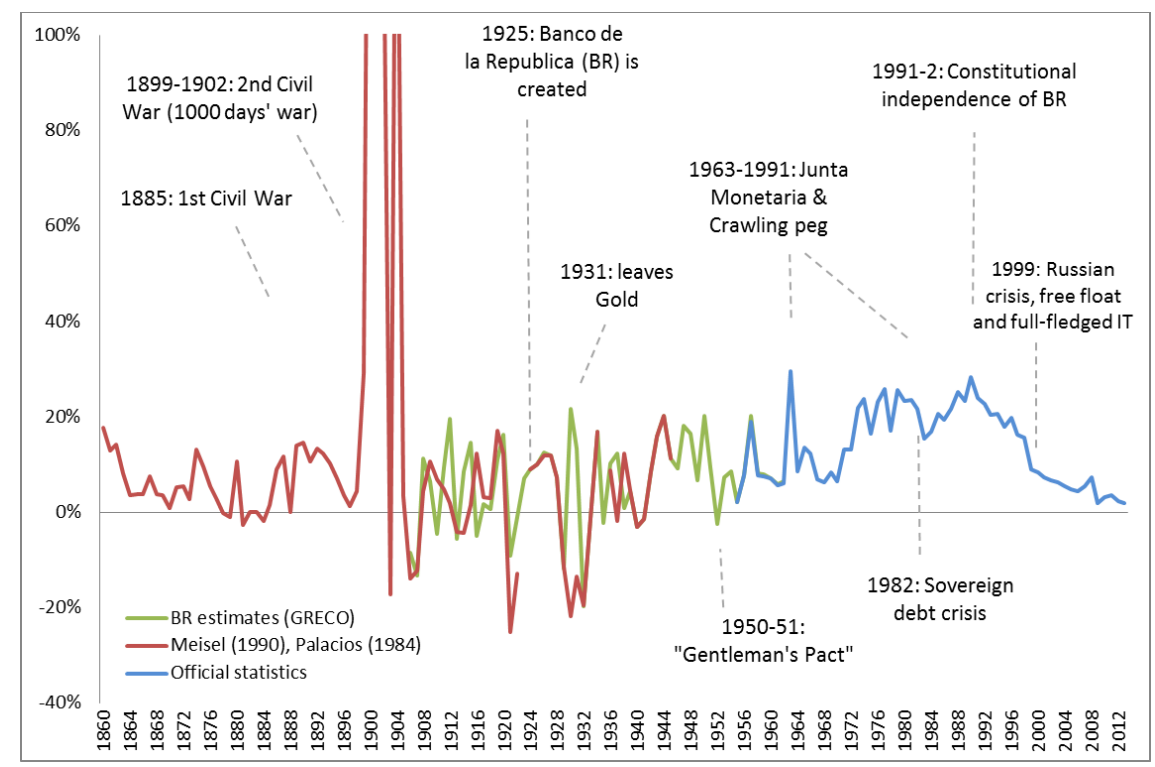




\section{Figure 8. Inflation targeting in Colombia}

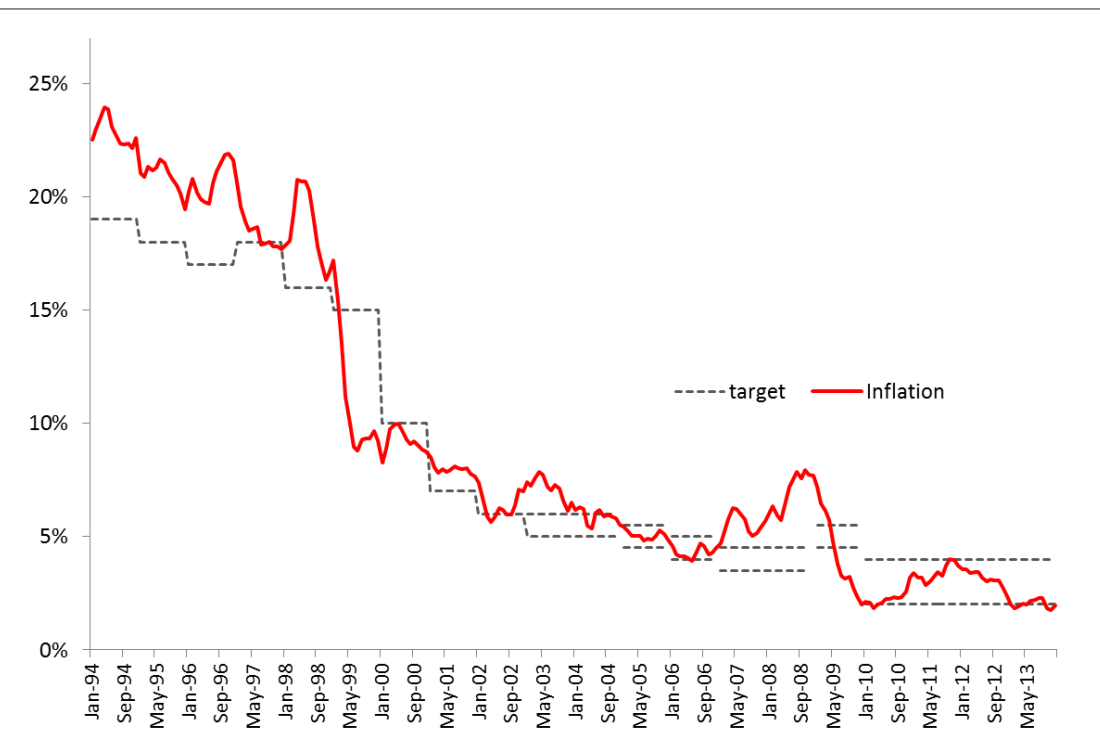

Source: Banco de la Republica

\section{Mexico $^{8}$}

Like the other Latin American countries examined in this paper Mexico had a chaotic monetary history in the nineteenth century.

After a long period of free banking and several episodes of high inflation and banking crises, the idea of having an official central bank was introduced into the 1917 Mexican Constitution. The details of such scheme were worked out by the “Comision de Reorganizacion Administrativa y Financiera" led by Edwin Kemmerer, and Banco de Mexico was finally created in 1925. The Bank grew out of the "Comision Monetaria", a government body aimed at containing the hyperinflation and banking collapse of the tumultuous Revolutionary years (1914-1917) when Mexico left the Gold Standard and embarked on excessive deficit spending. Before the creation of Banco de Mexico in 1925, a number of banks, especially Banco

\footnotetext{
${ }^{8}$ Much of this material was done by Cesar Tamayo at the IADB.
} 
Nacional de Mexico (Banamex), performed some of the functions currently associated with central banking (Marichal, 1994; 2006).

The initial period of slow progress toward becoming an operating monetary authority was suddenly interrupted by the financial turmoil of the 1930s. The aftermath of the Great Depression brought about the first attempt to enhance the consistency and credibility of Banco de Mexico's policies with the introduction of the 1932 Monetary Act. This piece of legislation eliminated the Bank's retail banking operation, and let the Mexican currency to float while allowing the central bank to intervene the gold market. A short period of stability followed and the confidence in the national currency grew, which in turn allowed the central bank to established itself as a the sole monetary authority. A second lift to the central bank's credibility came in 1936 with the Bank's new Organic Law which introduced strict limits to the amount of credit that the Bank could grant the government effectively limiting the scope of deficit spending that could be financed by the inflation tax.

As in most developing countries, the history of central banking in Mexico has been intimately linked to its external and fiscal accounts (and by implication to its exchange rate). In fact, the pass-through effect from exchange rate to inflation has been traditionally large (Perez-Lopez Elguezabal, 1996) and sovereign debt/currency crises have usually resulted in (at least temporary) inflationary bouts. These features of the Mexican economy have often resulted in episodes of severe fiscal dominance and foreign exchange market interventions, both of which have undermined the credibility of the (often halfhearted) disinflationary efforts. While a balance of payments crisis in 1936 forced the bank to devalue the Peso, the 
wave of capital inflows that came with World War II (as investors sought safe heaven) put Banco de Mexico to the test regarding its commitment to fend off inflationary pressures stemming from fast money creation. Open market operations were used for the first time and, more importantly, the reserve requirement, first used in 1948, became the main policy instrument. Reserve requirements would be the backbone of Banco de Mexico's policy for the following four decades.

By adhering to the Bretton Woods (BW) system in 1944, Mexico again fixed its exchange rate in a clear effort to borrow credibility from abroad, following a spike in inflation which reached its (up to then) all-time high in 1944. During the capital inflows surge of 1949, the policy of high reserve requirements (close to $100 \%$ in some cases) was commonplace. With the inevitable capital flow reversals that followed, substantial devaluations were needed in 1948, 1949, 1950 and 1955, a practice that did a poor service to the credibility of the monetary regime, and ultimately meant that U.S. money growth was not a much of an anchor for Mexican monetary policy. After the last devaluation in 1955, however, and as a key element of a recently devised economic stabilization plan ("stabilizing development"), the central bank strengthened its commitment with the fixed exchange rate regime. Available estimates suggest that the elasticity of domestic money growth to changes in U.S. money growth was indeed larger during the 1955-73 period than during 1948-54 (Barro 1979), a clear sign that the central bank intended to increase the credibility of the regime.

Throughout the 1950s and 1960s, the reputation of the central bank grew hand in hand with that of two major figures, Rodrigo Gomez and Antonio Ortiz Mena, 
respectively Governor of Banco de Mexico and Secretary of Finance for most of that period. Turrent-Diaz (2007) calls this the period of central bank "charismatic autonomy" since, despite the legal impairments to central bank independence introduced in the 1930s and 1940s, the Bank's autonomy was safeguarded by the intellectual prestige and charisma of its leaders (Gomez and Ortiz-Mena). In other words, central bank independence was achieved in a de facto matter rather than assured by de jure means. The strong commitment to the BW system by both monetary and fiscal authorities resulted in the adoption of policies consistent with the exchange rate regime. Accordingly, for most of the 1955-70 period, the government increased its deficit spending only at rates slightly above that of real economic growth and the central bank did precisely the same with the money supply (Wilford and Zecher 1979). In turn, the consistency of fiscal and monetary policies during this period reinforced central bank credibility. These were years of growth and relative stability: between 1955 and 1970 real income grew at an average of $7 \%$ while inflation averaged $4 \%$ per year (see the "charismatic" autonomy period).

During the 1970s and the early 1980s, severe balance of payments and debt crises hit the Mexican economy. It was amidst the turbulent events of 1982 (the so-called "debt crisis") that the central bank was given a new boost of independence with the constitutional amendment of Article 28, which now established a "decentralized" Banco de Mexico. Such institutional reform did little to prevent the damage that macroeconomic instability would inflict upon the central bank's credibility, however. In the years following the debt crisis, Mexico experienced significant 
financial distress, exchange rate depreciations and the inflation rate climbed to above $100 \%$ per year. While the central bank had not adopted an inflation target strategy by this time, the inflationary eighties severely undermined its credibility. All this resulted in a number of sectors (workers, businessmen, policymakers) coming together in December 1987 to sign an economic pact ("Pacto de Solidaridad Economica", PSE) in an effort to make inflation control a policy priority. Although inflation did not recede immediately -and in fact kept rising until 1988 following sustained depreciations- it eventually fell to around 20\% in mid-1989.

A major enhancement to central bank credibility came in 1993, when Article 28 was amended again to grant full administrative and operational autonomy to Bank of Mexico, as well as an explicit mandate to guard purchasing power. This new amendment was part of a broader wave of market-oriented institutional reforms that took place during the 1988-1994 "sexenio". The relative success of the "Pacto" in terms of falling inflation (which hovered around 7\% in 1994) and accelerating economic growth, along with a generalized shift toward economic liberalism both inside and outside Mexico were the main forces underlying these important transformations. In 1988 Mexicans elected Carlos Salinas de Gortari -a Harvardtrained economist- as their president who, in due course, pursued an aggressive policy of privatizations and trade liberalization. Moreover, Salinas de Gortari also favored monetary orthodoxy and financial liberalization, and, in 1993 put forth the aforementioned amendment aimed at strengthening central bank independence and monetary policy credibility. The new law also established overlapping appointments for the Governor and Deputy Governors which are appointed by the incumbent 
president halfway through the presidential period, but cannot be removed by the incoming one. With the introduction of these changes in the Bank's workings and scope, the period after 1993 is characterized by Turrent-Diaz (2007) as one of "institutional" central bank autonomy, where independence is rooted on solid legal and constitutional grounds, as well as on a widespread popular support.

After only three years of relative stability and falling inflation rates, the Tequila crises put the central bank to the test once again. The years of large capital inflows and high private and public spending gave way to several months of severe financial distress. While the short maturity of dollar denominated debt was at the heart of the debt crisis, it was the capital flows reversal which exposed the conflict between the Central Bank's exchange rate policy and its low-and-stable inflation goal (the "trilemma" of international finance). As the need for a large exchange rate adjustment grew, the credibility of both policies was heavily undermined, which ultimately led to a currency crisis and a bout of inflation, with the exchange rate depreciating more than 100\% in December 1994 and annual inflation reaching over 40\% in early 1995 (Carstens and Werner 2000). These developments forced the Mexican authorities to pursue a rapid transition toward a floating exchange rate regime and a monetary regime based solely on price stability.

The need to rehabilitate the much damaged central bank credibility in the face of a depreciation-fueled inflation spike can help explain why short term interest rates continued to rise substantially even after abandoning the currency band. However, regaining credibility in the monetary policy strategy would require a combination of increasing monetary control and the leadership of Guillermo Ortiz Martínez, the 
technocrat with a sterling reputation who had weathered the 1994-5 crisis as Finance Secretary. Once the Peso was allowed to float, the central bank could finally adopt an inflation targeting (IT) approach in 1996, first as an internal strategy and finally as a public commitment in 2001. The bank also drifted away from its quantity-based instrument approach (reserve requirements) and into a price-based instrument such as short term interest rates in the way modern central banks set the monetary policy stance. Under the new exchange rate and monetary regime (IT), a series of additional measures were taken in order to strengthen the credibility of Banco de Mexico. In particular, Open Market Operations are now more flexible than before (the equilibrium rate is completely free of intervention), the Bank exerts a more rigorous control over domestic credit growth, and the entire monetary policy strategy is now extensively documented and communicated to participants of both financial and real markets (Werner and Carstens 2000).

All in all, the most recent monetary regime (IT) has enjoyed widespread success. For one, there is ample evidence that the exchange pass-through has dropped significantly under the new regime (Cortes 2013). This has reinforced the central bank's instrument independence and has made credible announcements that priority is given to price stability and not exchange rate targeting. Indirect evidence of such credibility can be found in the systematic efforts by the corporate sector to reduce their foreign currency debt in the expectation that, when pressed, the central bank will rather concentrate on inflation than defend any hypothetical exchange rate level (Martinez and Werner, 2002). Similarly, several characterizations of inflation through its time-series properties portray the process as non-stationary 
before the year 2000, but stationary thereafter (Chiquiar et al. 2010), reflecting the fact that the announcement of inflation targets has served as an effective (credible) nominal anchor. In fact, 12-month inflation expectations reached its all-time low in 2007, at 3.5\% and its dispersion has decreased consistently since the adoption of the IT regime (Garcia-Verdu, 2012). A final piece of evidence suggestive of the relatively high credibility of Banco de Mexico's policies is reflected in the backward/forward looking nature of price setting by firms (which also embeds the outcomes of wage bargaining). Ramos-Francia and Torres (2006) provide conclusive evidence that after 1997, the gradual fall in inflation has resulted in firms adjusting their prices less frequently and becoming more forward-looking (than in the years prior to 1997) in their price setting-behavior.

Figure 9. Inflation in Mexico

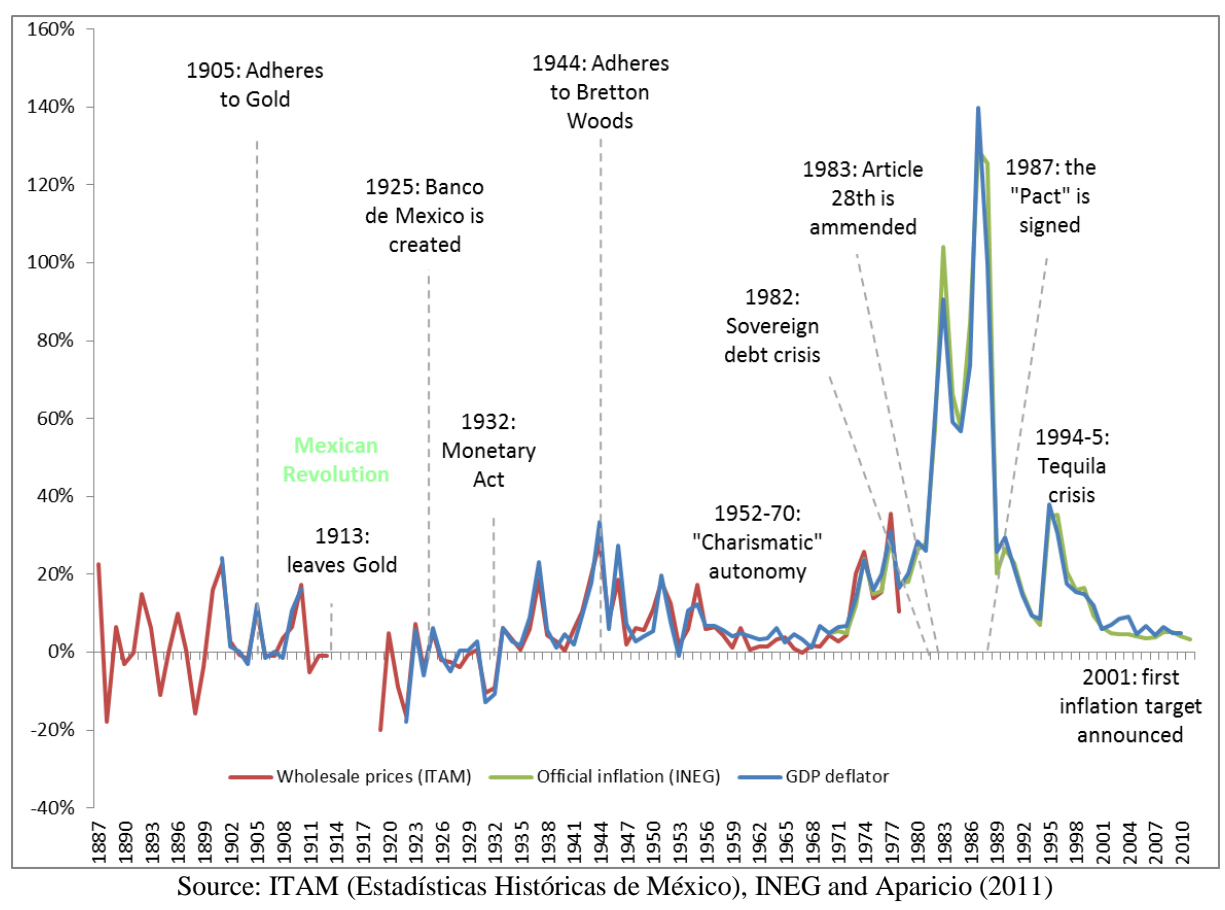




\section{A Summing Up}

The three narratives for the advanced countries illustrate the pendulum nature of the evolution of central bank credibility. The case of the three emerging countries is vastly different. These countries had little exchange rate credibility before they adopted central banks and this prevailed until at least the 1980s. The record of the twentieth century was one of high inflation and frequent currency and banking crises and occasional debt crises. In the 1980s following the example of the advanced countries the three Latin countries implemented policies to achieve credibility by aiming for low and stable inflation. In each case the decision to grant central bank independence from the fiscal authorities and then adopt a form of inflation targeting in the 1990s has led to a significant reduction so far, in inflation and the ushering in of central bank credibility.

\section{Some Empirical Evidence on the Pendulum of Central Bank Credibility}

Our empirical investigation analyzes the credibility performance of 10 central banks. They are: Canada, France, Japan, Germany, Italy, Norway, Sweden, Switzerland, The UK and the US. We rely on annual data going back to when the central banks were established. The data are described in Bordo and Siklos (2014). A Summary of Credibility across Regimes

Table 2 presents a summary record of the evolution of credibility across the three main policy regimes for the ten countries. We compare the means and standard deviations of observed inflation and a measure of the implicit inflation objective as 
defined in equation (1) above based on a Taylor Rule as developed in Bordo and Siklos (2014). The purpose of the table is to determine the differences between observed inflation and what the model suggests was the implied average inflation objective of the central bank throughout the regime.

The results in the table suggest that central banks inflation objectives and actual inflation can be far apart. This could be because central banks practiced considerable discretion, or because of large shocks which creates a wedge between the observed and the implicit inflation objective.

In more detail, based on a comparison of mean observed inflation across the gold standard (GS), Bretton Woods (BW), and price stability regimes (PS), we conclude that GS has the lowest observed inflation rate; PS delivers the second lowest inflation rate and BW is the highest. Thus the two regimes that had credible nominal anchors delivered the best average inflation outcome.

A comparison of the standard deviations of the observed inflation rate shows that: GS has the highest volatility of observed inflation and PS the lowest. The low volatility of PS is a reflection of the Great Moderation. The high volatility of GS relative to the other regimes may reflect the fact that the regime was focused on price level stability rather than the inflation rate stability that characterizes the PS regime.

A comparison of central bank implicit inflation rate objectives (based on rolling estimates of the central bank's inflation objective) reveals that both GS and PS have the lowest inflation objectives so that it appears that the GS and PS regimes "tie the hands" of policy makers. 
Table 2. Summary Record of Main Monetary Policy Regimes: Means and Standard Deviations

\begin{tabular}{|c|c|c|c|c|}
\hline Country & Regime $^{1}$ & Years & Observed inflation ${ }^{4}$ & $\begin{array}{c}\text { Implicit Inflation } \\
\text { Objective (rolling) }\end{array}$ \\
\hline \multirow[t]{3}{*}{ U.S. } & GS & $1922-1933$ & $-2.25(4.54) \mathrm{T}=12^{5}$ & $2.45(4.81) \mathrm{T}=4$ \\
\hline & BW & 1959-1971 & $2.55(1.72), \mathrm{T}=12$ & $3.52(0.80) \mathrm{T}=4$ \\
\hline & PS & $1981-2008$ & $3.08(7.82) \mathrm{T}=22$ & $3.08(1.68) \mathrm{T}=4$ \\
\hline \multirow[t]{4}{*}{ U.K. } & GS & $\begin{array}{c}\text { 1844-1914, } 1922- \\
1931\end{array}$ & $-0.21(5.11) \mathrm{T}=11$ & $7.94(3.70) \mathrm{T}=25$ \\
\hline & BW & 1959-1972 & $4.15(2.46) \mathrm{T}=13$ & $1.67(2.36) \mathrm{T}=4$ \\
\hline & GM & $1985-2007$ & $3.10(2.19) \mathrm{T}=23$ & $-1.72(3.01) \mathrm{T}=7$ \\
\hline & PS & 1992-2008 & $2.65(0.96) \mathrm{T}=17$ & $0.40(1.33) \mathrm{T}=5$ \\
\hline \multirow[t]{4}{*}{ Norway } & GS & $\begin{array}{c}1875-1914,1928- \\
1931\end{array}$ & $-0.36(2.05) \mathrm{T}=44$ & $-0.36(2.05) \mathrm{T}=14$ \\
\hline & BW & 1959-1972 & $4.24(2.36) \mathrm{T}=14$ & $4.77(3.88) \mathrm{T}=4$ \\
\hline & GM & $1985-2007$ & $3.07(2.04) \mathrm{T}=23$ & INS $^{2}$ \\
\hline & PS & 2001-2008 & $1.93(1.12) \mathrm{T}=8$ & INS \\
\hline \multirow[t]{4}{*}{ Sweden } & GS & $\begin{array}{c}\text { 1873-1914, } 1922- \\
1931 \\
\end{array}$ & $-0.68(4.82) \mathrm{T}=52$ & $-0.68(4.82) \mathrm{T}=11$ \\
\hline & BW & 1959-1974 & $4.59(2.30) \mathrm{T}=16$ & $3.48(1.38) \mathrm{T}=5$ \\
\hline & GM & $1985-2007$ & $3.30(2.67) \mathrm{T}=23$ & $4.79(2.04) \mathrm{T}=8$ \\
\hline & PS & 1994-2008 & $4.59(2.30) \mathrm{T}=16$ & $-0.75(0.62) \mathrm{T} 5$ \\
\hline \multirow[t]{4}{*}{ Germany } & GS & $\begin{array}{c}\text { 1871-1914, 1924- } \\
1931 \\
\end{array}$ & $0.44(2.48) \mathrm{T}=33$ & $1.60(1.89) \mathrm{T}=8$ \\
\hline & BW & 1959-1973 & $3.01(1.63) \mathrm{T}=15$ & $1.56(1.91) \mathrm{T}=4$ \\
\hline & GM & $1985-2007$ & $1.96(1.25) \mathrm{T}=23$ & $8.32(8.81) \mathrm{T}=8$ \\
\hline & PS & 1993-2008 & $1.80(0.97) \mathrm{T}=16$ & $-0.87(4.19) \mathrm{T}=5$ \\
\hline \multirow[t]{4}{*}{ Switzerland } & GS & $1878-1914$ & $1.94(1.92) \mathrm{T}=8$ & INS \\
\hline & BW & $1959-1972$ & $3.31(1.87) \mathrm{T}=14$ & $3.13(3.24) \mathrm{T}=5$ \\
\hline & GM & $1985-2007$ & $1.78(1.56) \mathrm{T}=23$ & $1.25(14.37) \mathrm{T}=8$ \\
\hline & PS & $1973-2008$ & $2.69(2.94) \mathrm{T}=36$ & $4.02(5.02) \mathrm{T}=10$ \\
\hline \multirow[t]{4}{*}{ Canada } & GS & $\begin{array}{c}\text { 1854-1914, 1926- } \\
1929\end{array}$ & NA & $\mathrm{NA}^{3}$ \\
\hline & BW & $1960-1970$ & $2.49(1.40) \mathrm{T}=11$ & $3.04(0.40) \mathrm{T}=4$ \\
\hline & GM & $1985-2007$ & $2.61(1.39) \mathrm{T}=23$ & $-1.01(0.51) \mathrm{T}=5$ \\
\hline & PS & 1991-2008 & $1.90(1.01) \mathrm{T}=17$ & $0.59(3.21) \mathrm{T}=4$ \\
\hline \multirow[t]{4}{*}{ Italy } & GS & $\begin{array}{c}\text { 1902-1917, } 1927- \\
1934\end{array}$ & $-1.58(4.33) \mathrm{T}=19$ & $-3.63(6.25) \mathrm{T}=6$ \\
\hline & BW & 1959-1972 & $3.61(1.96) \mathrm{T}=14$ & $3.85(0.70) \mathrm{T}=4$ \\
\hline & GM & $1985-2007$ & $3.87(1.90) \mathrm{T}=23$ & $9.79(6.34) \mathrm{T}=7$ \\
\hline & PS & 1993-2008 & $2.82(1.02) \mathrm{T}=16$ & $4.64(1.43) \mathrm{T}=4$ \\
\hline \multirow[t]{4}{*}{ France } & GS & $\begin{array}{c}\text { 1878-1914, } 1926- \\
1936\end{array}$ & $0.40(6.54) \mathrm{T}=48$ & NA \\
\hline & BW & $1960-1973$ & $4.43(1.40) \mathrm{T}=14$ & $0.11(7.29) \mathrm{T}=5$ \\
\hline & GM & $1985-2007$ & $2.15(0.93) \mathrm{T}=23$ & $-4.90(11.36) \mathrm{T}=7$ \\
\hline & PS & 1993-2008 & $1.63(0.57) \mathrm{T}=15$ & NA \\
\hline \multirow[t]{4}{*}{ Japan } & GS & $\begin{array}{c}\text { 1897-1917, } 1930- \\
1931\end{array}$ & $3.20(9.67) \mathrm{T}=23$ & $3.94(1.67) \mathrm{T}=8$ \\
\hline & BW & 1959-1977 & $6.96(4.32) \mathrm{T}=19$ & NA \\
\hline & GM & $1985-2007$ & $0.63(1.22) \mathrm{T}=23$ & $5.38(5.08) \mathrm{T}=6$ \\
\hline & PS & 1998-2008 & $-0.15(0.64) \mathrm{T}=11$ & $-0.20(0.02) \mathrm{T}=2$ \\
\hline
\end{tabular}

Source: Bordo and Siklos (2014).

Notes: (1) GS is the Gold Standard; BW is Bretton Woods; PS is the price stability objective, and GM is the Great Moderation; (2) INS means insufficient data to perform the calculations; (3) NA means not available or no data (e.g., the central bank did not exist); (4) T is the number of observations; (5) With some exceptions the calculations assume that an interest rate instrument is used. The exceptions are: money growth instrument for the BW period, exchange rate instrument (BW for Norway and France, GS for Italy). The calculations are based on the procedures detailed in Bordo and Siklos (2014) where the estimates are based on a 10 year window that is rolled 5 years at a time. Again, see Bordo and Siklos (2014) for the details; (4) Standard deviations in parenthesis. 
Finally, a comparison of the standard deviation of the central banks' implicit inflation rate objective shows that PS has the lowest standard deviation in most countries. Thus the moderating effect on price variability found for observed inflation is mirrored by relatively low variability in the central banks' inflation rate objective.

\section{A Measure of the Probability a Regime is Credible}

Next, we ask how monetary policy regimes impact credibility in probabilistic terms. We ask if, for example, GS raises or reduces the likelihood that a regime is credible? We use a Tobit regression where the dependent variable is the measure of credibility estimated from equation (1) above from Bordo and Siklos (2014). If the estimate of credibility is greater than 1 (i.e., a $1 \%$ difference between actual inflation and the central bank's objective) then we assign a value of one to the dependent variable. Otherwise a zero is assigned. This means that if observed inflation deviates from the central bank's inflation objective by more than $1 \%$ we effectively assume a loss of credibility. Otherwise, deviations of less than $1 \%$ mean the loss of credibility.

Table 3. Tobit analysis for credibility

\begin{tabular}{|l|c|c|c|}
\hline Country & Gold Standard & Bretton Woods & $\begin{array}{l}\text { Price Stability } \\
\text { Objective }\end{array}$ \\
\hline Sweden & - & 0 & 0 \\
\hline U.K. & - & 0 & - \\
\hline France & - & 0 & - \\
\hline Norway & - & 0 & + \\
\hline Germany & + & 0 & INS \\
\hline Japan & 0 & + & + \\
\hline Italy & - & + & + \\
\hline Switzerland & INS & + & - \\
\hline USA & INS & 0 & + \\
\hline Canada & INS & - & + \\
\hline
\end{tabular}

Note: +/- indicates the sign of the statistically coefficient on the variable of interest. INS means that there was insufficient or no data. A 0 indicates that the coefficient was not statistically different from zero even at the $10 \%$ level of significance. 
Table 3 shows the results. A negative sign implies an increase in credibility, a positive sign is interpreted as fall in credibility and a zero means that no statistically significant link is found between the type of regime and credibility. INS means insufficient data. The results in Table 3 show that in 5 out of 7 countries where we had sufficient data, the GS increases credibility. Only for Germany is credibility reduced while it is insignificant for Japan. BW reduces credibility in 8 out of 10 countries. It is insignificant for the U.S. Only for Canada was credibility raised.

\section{A Comparison of Actual versus Expected Inflation Across Regimes for 10 Countries}

Figure 10 compare actual with expected inflation. Expected inflation is the mean of the forecasts from three different models in Bordo and Siklos (2014) that allow for breaks, changes in persistence and moving averages. The closer expectations are aligned with observed inflation the smaller the difference between the two series and consequently, the more credible the central bank.

The key features that are apparent from these figures are: (1) that observed inflation and expected inflation are most closely aligned in the gold standard period because the dots are closer to the 45 degree line (here observed equals actual). However, this comes at the cost of much greater volatility in prices (see Table 2). This confirms the notion that the GS is akin to a price level target while inflation targeting (explicit or implicit) regimes permit drift. Consequently, inflation volatility has a strong moderating effect on inflation; (2) BW is the worst regime in terms of delivering credibility with the principal exception of Germany and Switzerland which have a strong "stability culture"; (3) Policy makers in the past two decades 
have emphasized the importance of price stability but how it is defined and the strategy used to achieve it differs across countries (e.g., inflation targeting versus a more flexible monetary policy strategy); (4) it is clear that among the inflation targeting (IT) countries in the sample (Canada, UK, Norway and Sweden) they have been far more successful at anchoring expectations in the recent PS period than in other countries where inflation is the declared aim. The only exceptions are Germany and Switzerland. This can be seen in the flatter scatter plots in the IT countries than elsewhere which means much less variation in expected inflation than observed inflation; (5) Even in countries that are not as successful in anchoring inflation expectations in the PS era there has been a large reduction in mean inflation relative to the BW era. Hence, there are potentially two separate benefits from PS: a mean reduction effect in inflation; and an enhancing effect with the latter an added benefit of IT regimes. 
Figure 10. Inflation versus Expected Inflation Across Regimes in 10 Countries Since the 19th Century
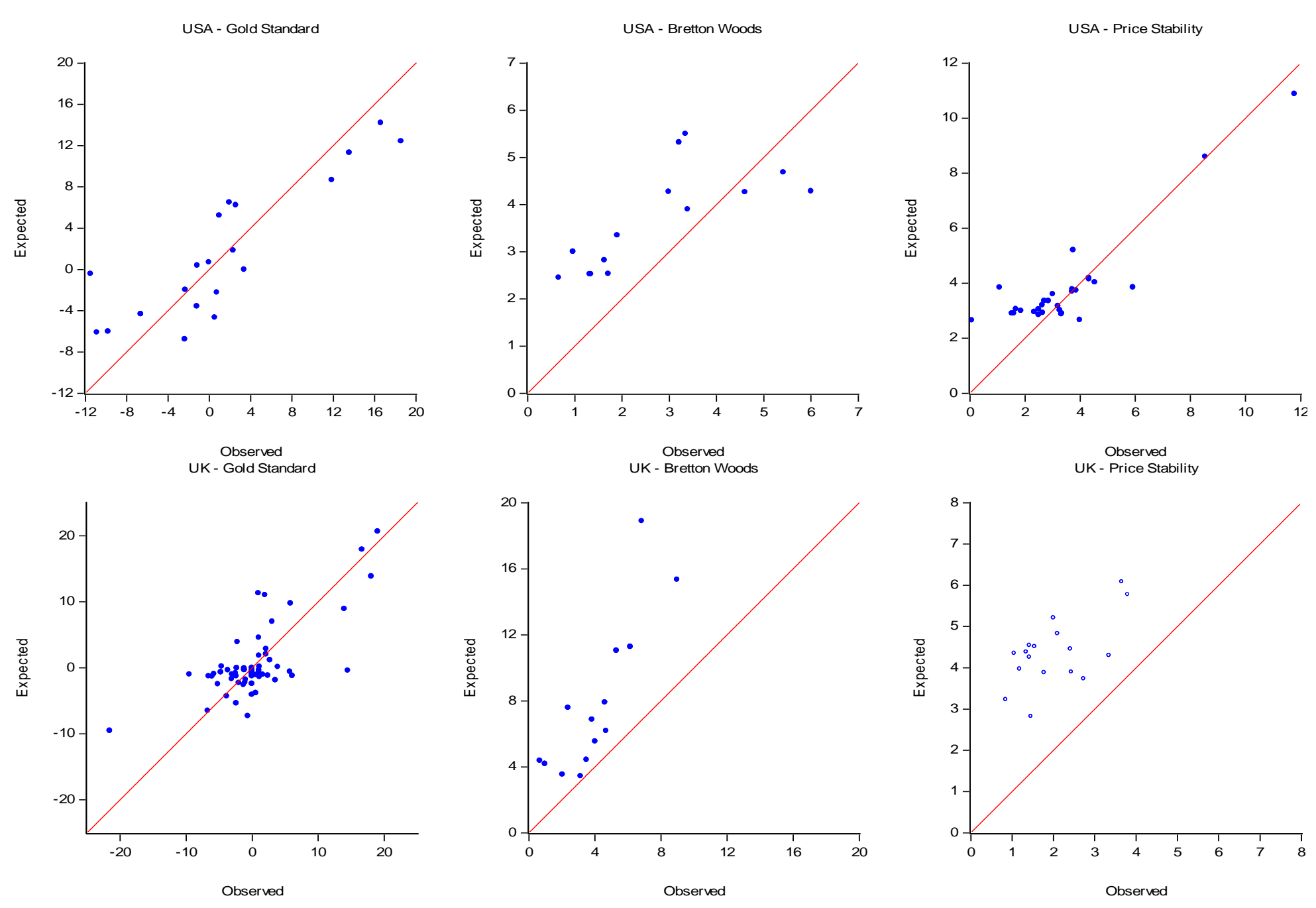

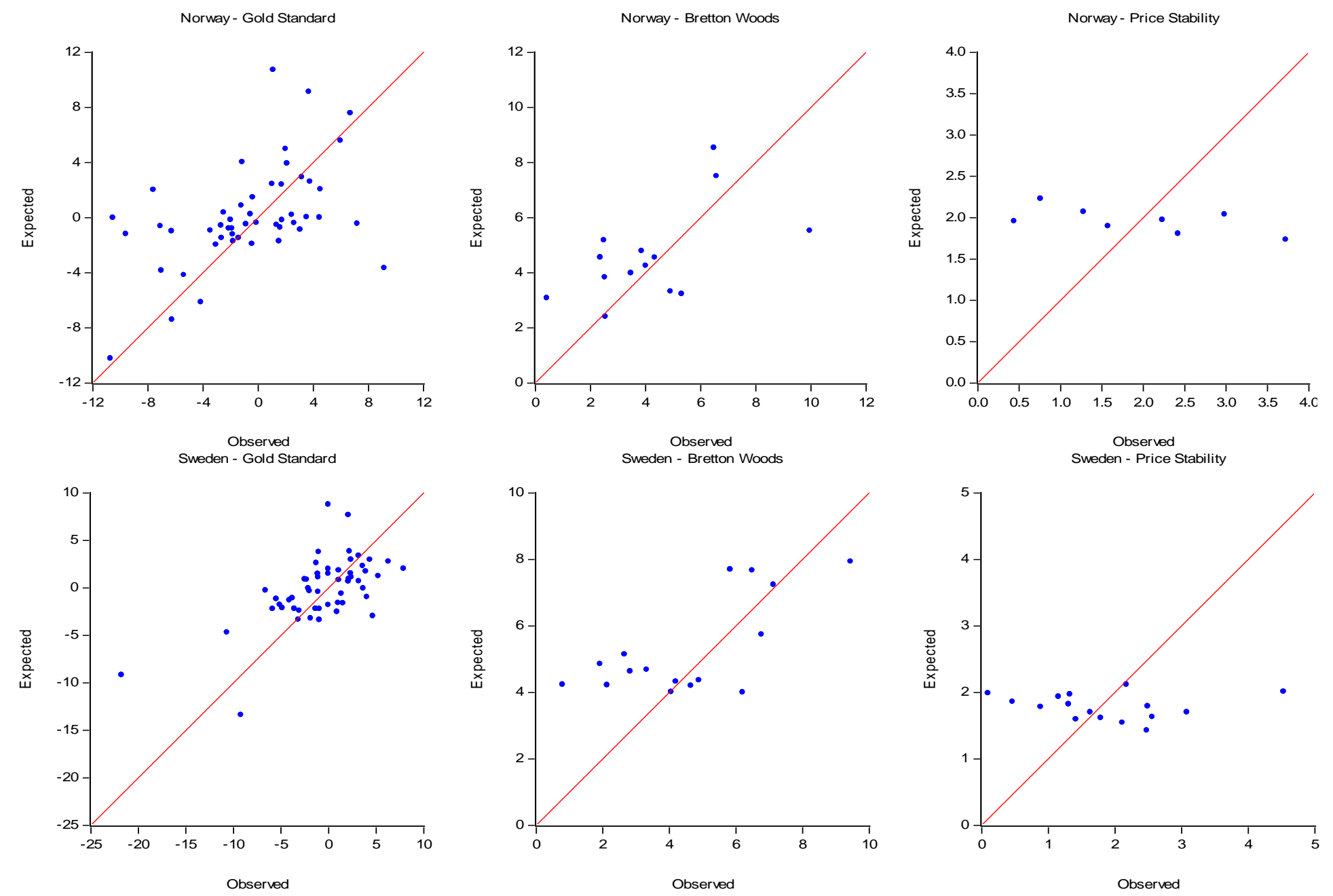
Germany - Gold Standard

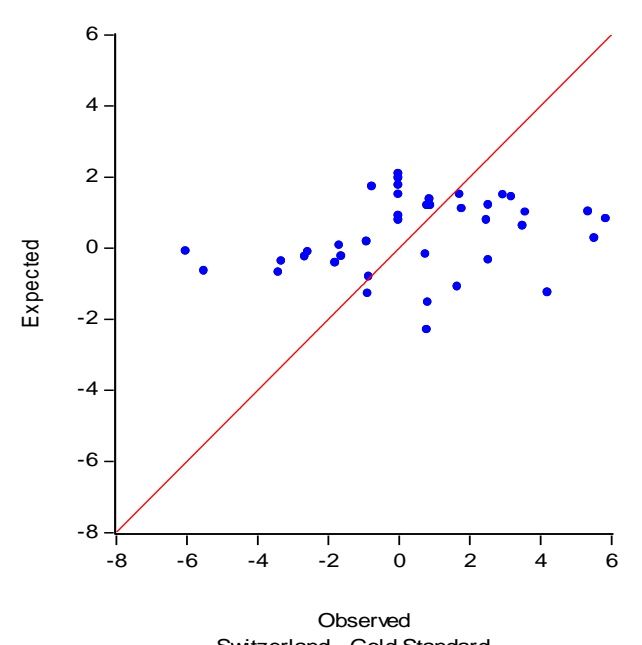

Switzerland - Gold Standard

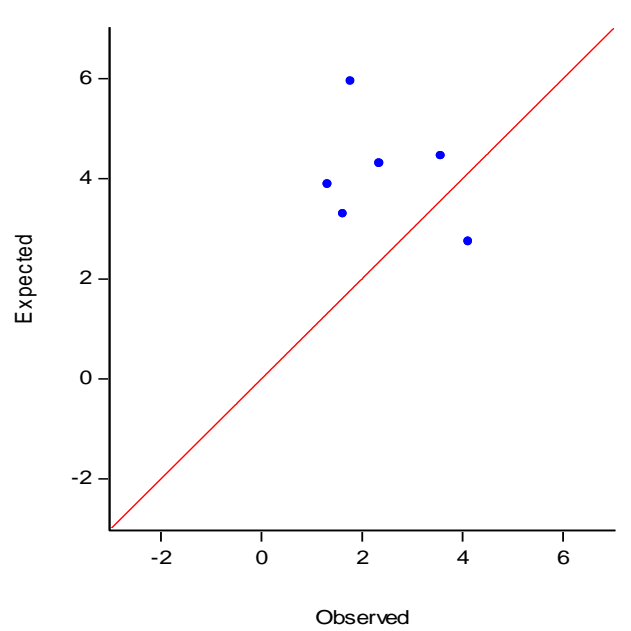

Germany - Bretton Woods

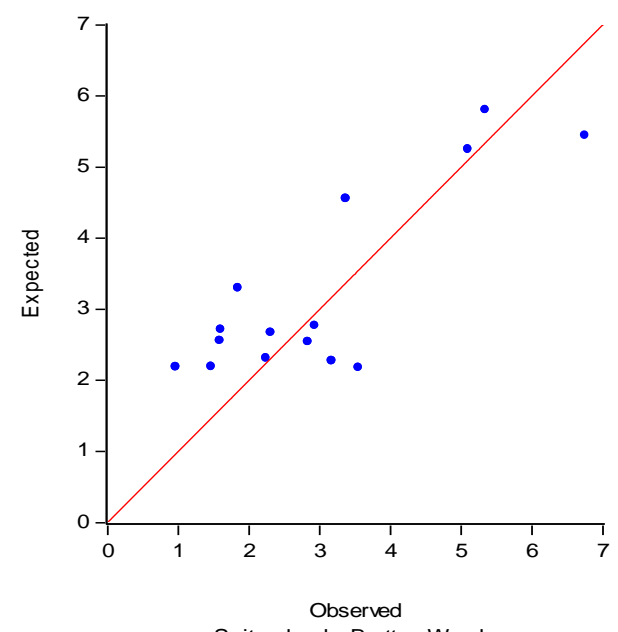

Switzerland - Bretton Woods

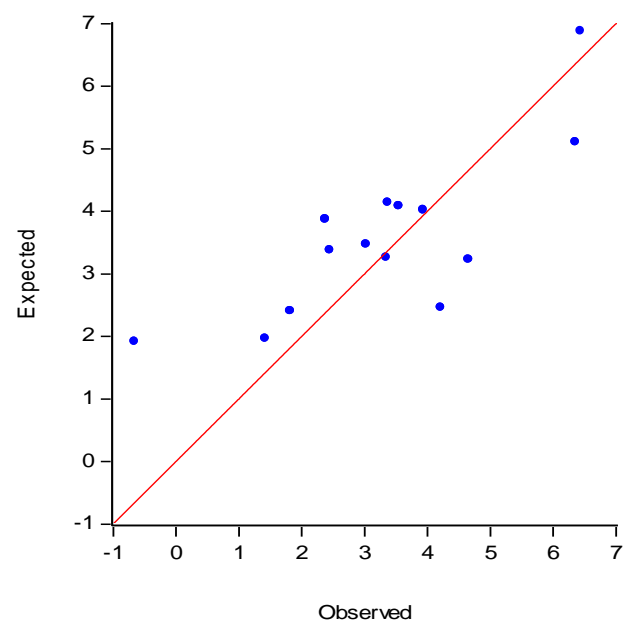

Germany - Price Stability

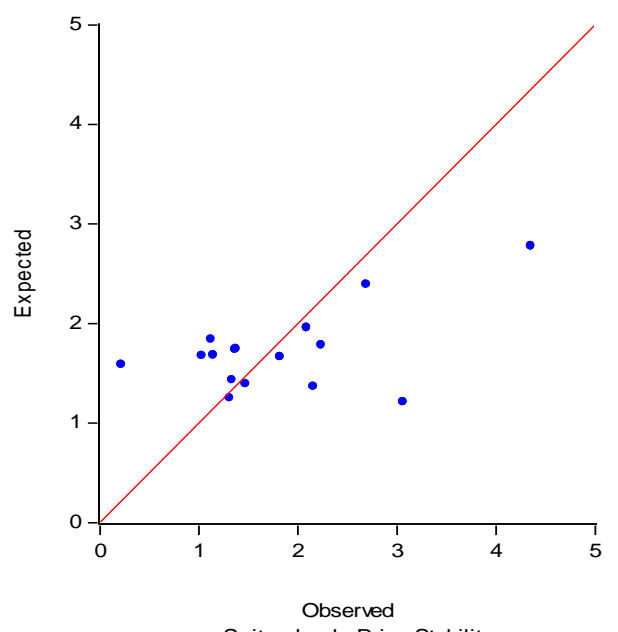

Switzerland - Price Stability

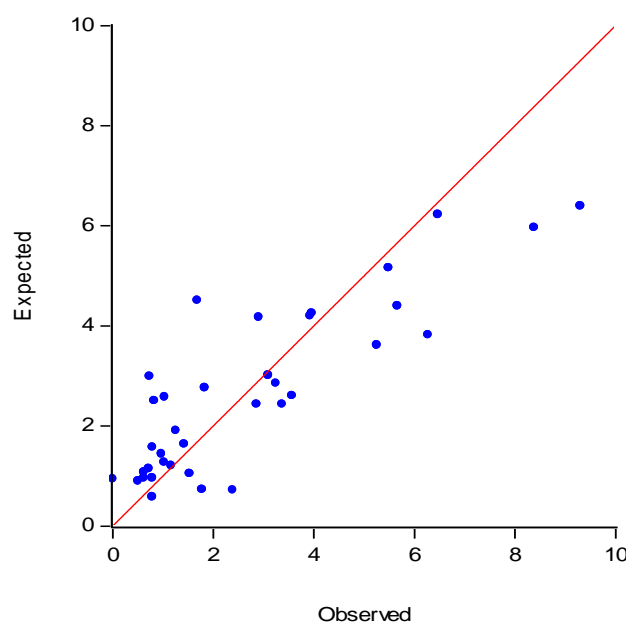


Canada - Bretton Woods

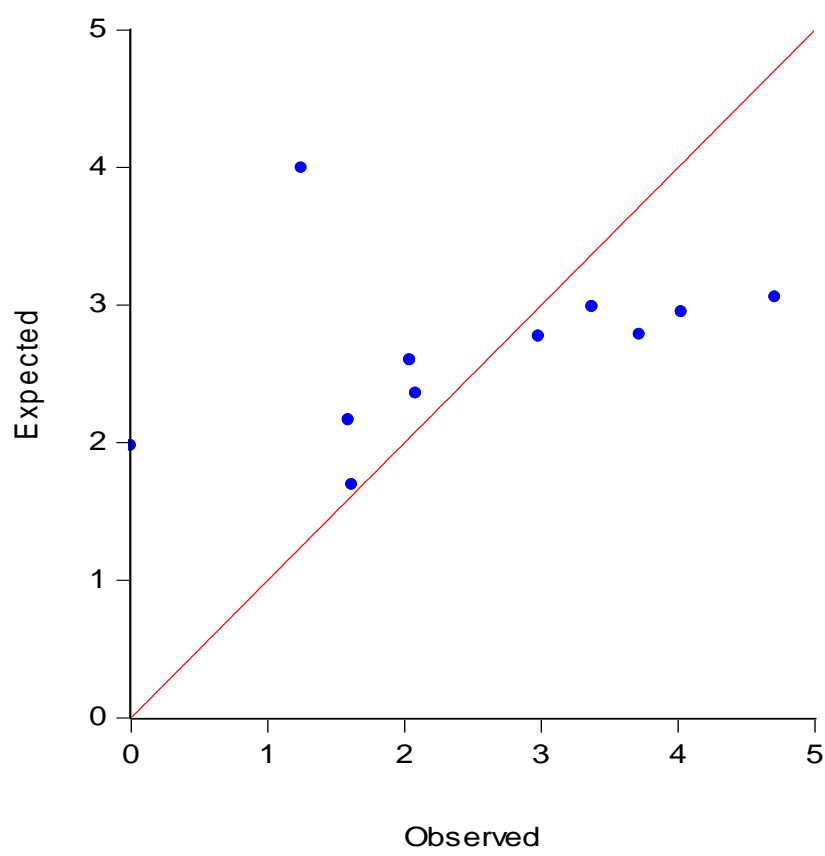

Canada - Price Stability

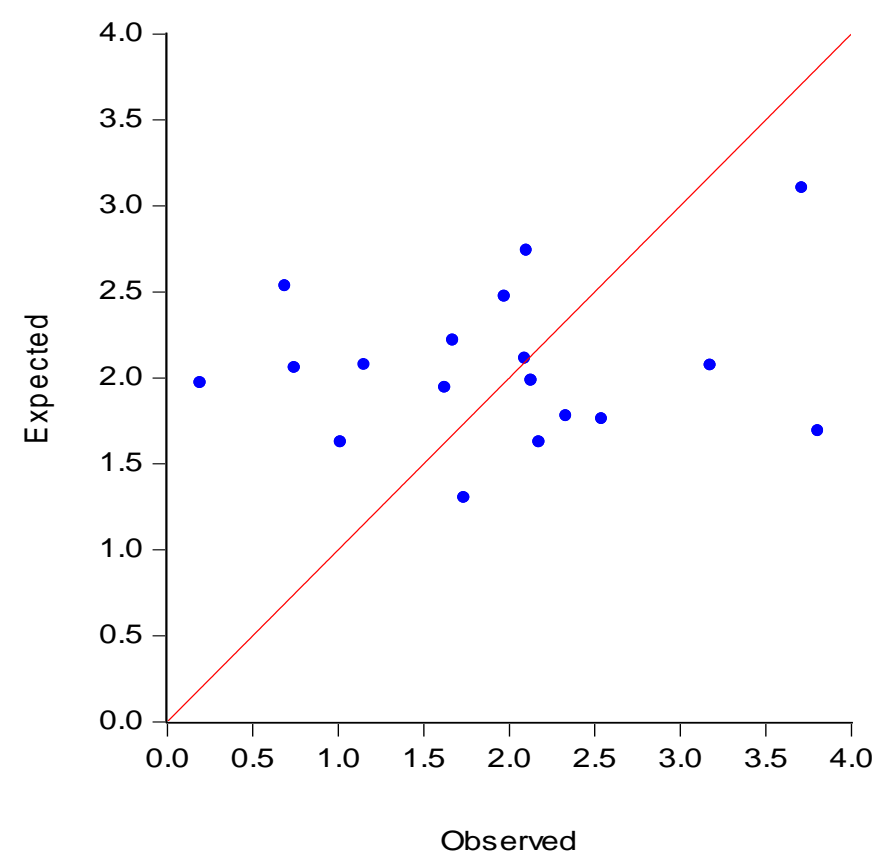


Italy - Gold Standard
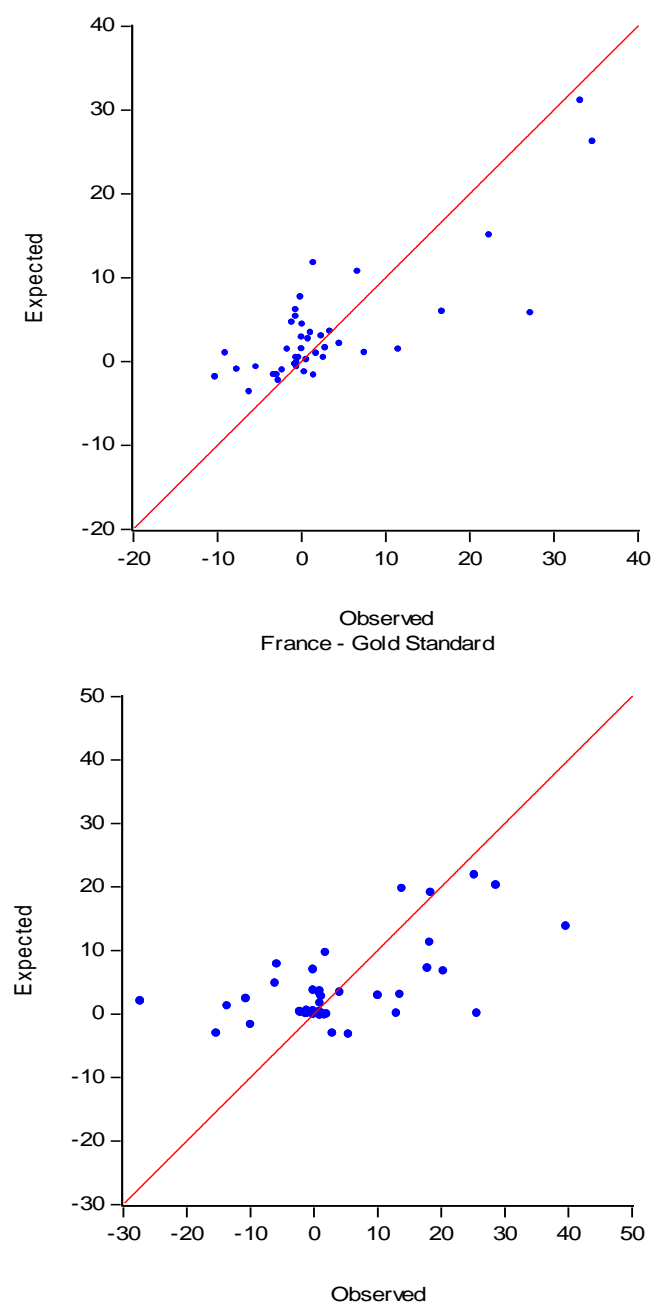

Italy - Bretton Woods
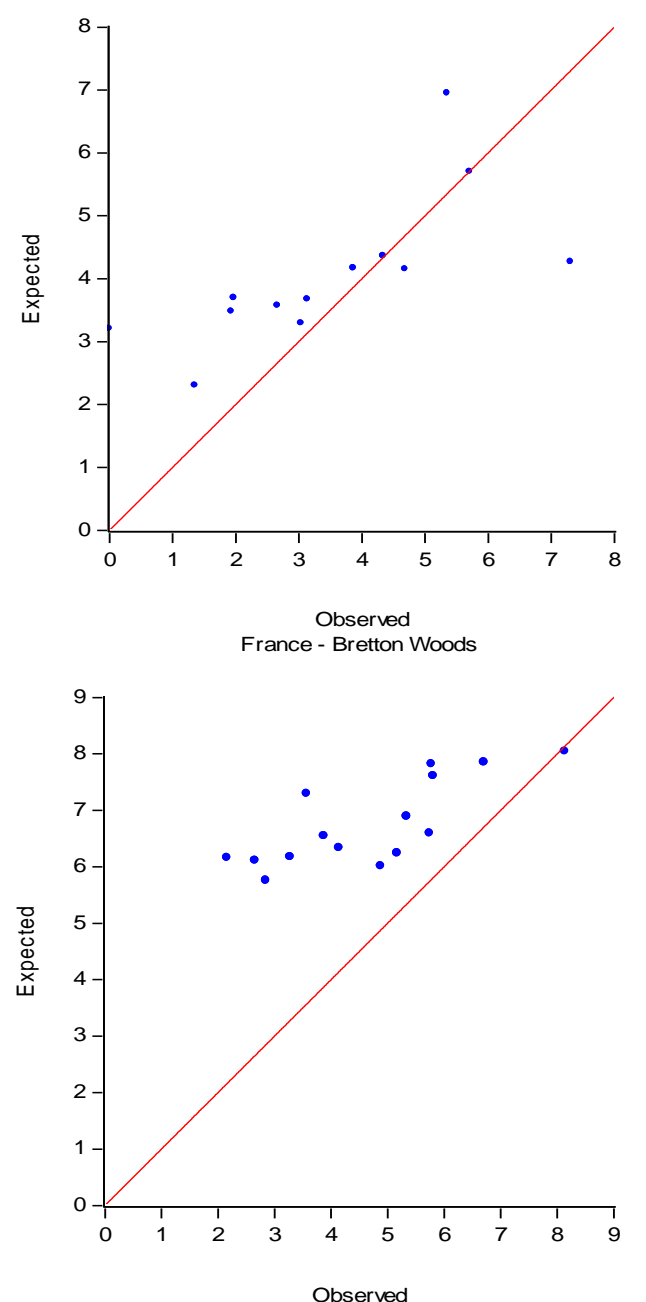

Italy - Price Stability
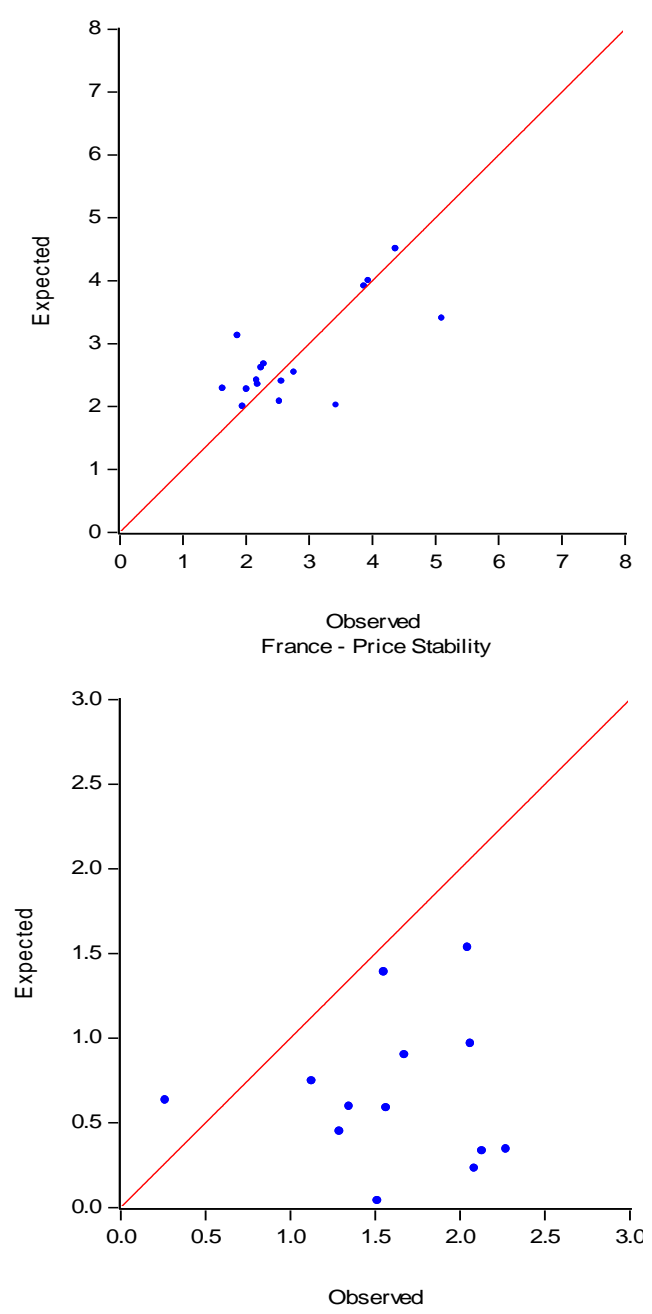

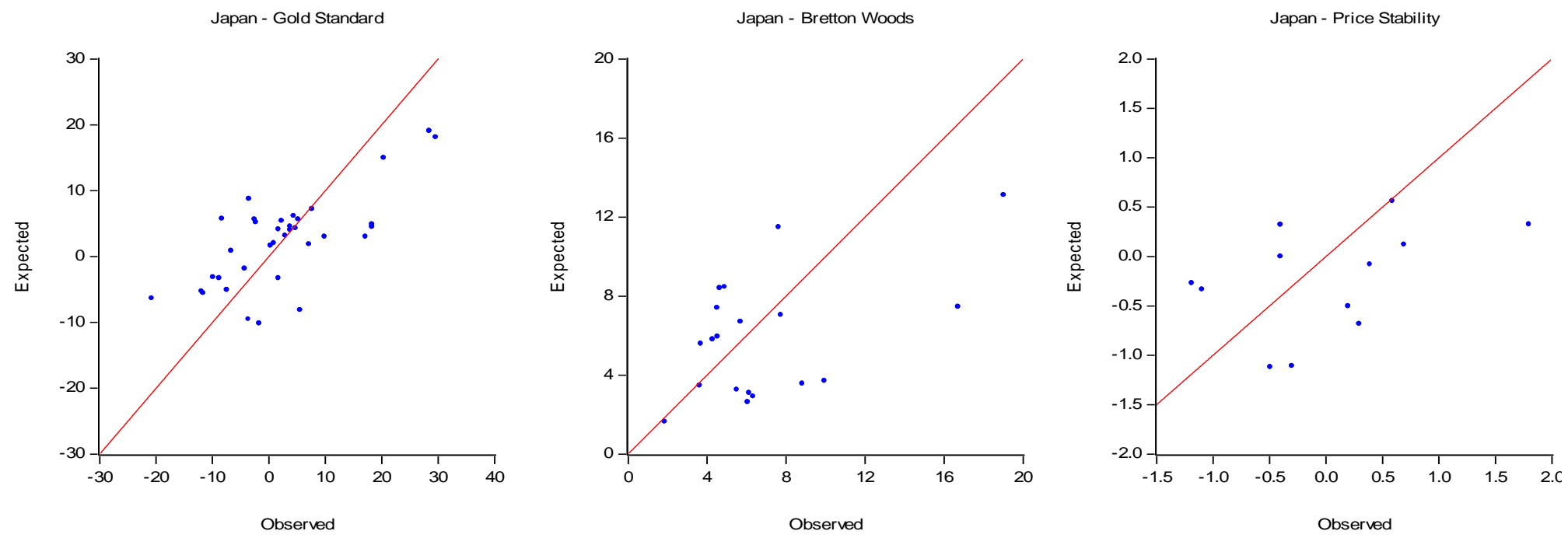

Notes: sample periods defined above ( Table 1). Expected inflation is based on the mean of three models of inflation. See Bordo and Siklos ( 2014). Observed inflation is the annual rate of change in the CPI. All data are from Bordo and Siklos (2014). 


\section{The Determinants of Credibility}

Table 4 explores the determinants of credibility using a panel regression. This is adapted from Table 2 in Bordo and Siklos (2014). The highlighted yellow boxes indicate statistical significance. Positive and negative signs at the top of the table indicate that separate estimates were generated according to whether observed inflation is ABOVE (+ve) or BELOW (-ve) the central bank's implicit inflation objective. It is an easy way to determine whether higher than desired inflation (according to the central bank) influences credibility different than if inflation is below the central bank's target. A positive coefficient indicates that credibility is reduced because the squared difference between observed and the inflation objective increases, and vice versa, when the coefficient is negative.

The principal results were that: (1) adhering to the gold standard raises credibility; (2) higher money growth reduces credibility but only when inflation is above the central bank's implicit inflation objective; (3) a rise in banking sector loans to GDP reduces credibility but only when inflation is below the implicit inflation objective; (4) greater central bank independence raises credibility. This is based on data since the 1950s; (5) the exchange rate regime is defined so that the higher the value of the variable the less flexible the exchange rate system. We find that less flexible systems reduce credibility except when inflation rises above the central bank's objective. This could reflect the fact that a peg can serve as an anchor for inflation; (6) we find that a rise in the sovereign debt to GDP ratio raises central bank credibility. This may reflect the significance of the CBI variable and the fact that the government will 
be constrained by a monetary policy determined to maintain the central bank's credibility.

Table 4. Table Panel Regression Estimates of the Determinants of Credibility

\begin{tabular}{|c|c|c|c|c|c|c|c|c|c|c|c|c|}
\hline & \multicolumn{2}{|c|}{$1871-2008$} & \multicolumn{2}{|c|}{$1950-2008$} & \multicolumn{2}{|c|}{$\begin{array}{c}1871-2008 \\
\text { +ve }\end{array}$} & \multicolumn{2}{|c|}{$\begin{array}{c}\text { 1871-2008 } \\
\text {-ve }\end{array}$} & \multicolumn{2}{|c|}{$\begin{array}{c}1950-2008 \\
\text { +ve }\end{array}$} & \multicolumn{2}{|c|}{$\begin{array}{c}\text { 1950-2008 } \\
\text {-ve }\end{array}$} \\
\hline $\begin{array}{l}\text { Ind. } \\
\text { Variables }\end{array}$ & Coeff. & s.e. & Coeff. & s.e. & Coeff. & s.e. & Coeff. & s.e. & Coeff. & s.e. & Coeff. & s.e. \\
\hline $\begin{array}{l}\text { Gold } \\
\text { Standard }\end{array}$ & $57.57+$ & 28.04 & NA & NA & $-3.67+$ & 1.55 & $-2.40 \ddagger$ & 1.49 & NA & NA & NA & NA \\
\hline $\begin{array}{l}\text { Money } \\
\text { growth }\end{array}$ & 2.71 & 2.73 & 5.47 & 6.27 & $0.20 *$ & 0.06 & $0.18^{*}$ & 0.06 & 0.07 & 0.06 & -0.04 & 0.05 \\
\hline $\begin{array}{l}\text { Loans to } \\
\text { GDP ratio }\end{array}$ & -1.16 & 1.74 & -0.58 & 1.32 & 0.02 & 0.02 & $0.06^{*}$ & 0.02 & $0.06 *$ & 0.02 & $0.08 *$ & 0.02 \\
\hline $\begin{array}{l}\text { Debt to GDP } \\
\text { ratio }\end{array}$ & -0.52 & 0.71 & 0.56 & 0.79 & -0.02 & 0.02 & -0.02 & 0.01 & $-0.07^{*}$ & 0.01 & $-0.07 *$ & 0.02 \\
\hline $\begin{array}{l}\text { Equity } \\
\text { returns }\end{array}$ & 0.60 & 0.56 & 0.79 & 0.69 & -0.01 & 0.01 & -0.01 & 0.01 & -0.01 & 0.01 & -0.00 & 0.01 \\
\hline $\begin{array}{l}\text { Oil price } \\
\text { shocks }\end{array}$ & 35.27 & 71.30 & -3.99 & 9.20 & $2.22+$ & 0.94 & 0.96 & 1.29 & $4.68^{*}$ & 0.97 & $3.58^{+}$ & 1.61 \\
\hline $\begin{array}{l}\text { Financial } \\
\text { Crises }\end{array}$ & $30.31+$ & 16.69 & $52.13 \ddagger$ & 32.05 & $0.55 \ddagger$ & 0.31 & 0.29 & 0.32 & 0.44 & 0.46 & 0.10 & 0.34 \\
\hline $\begin{array}{l}\text { Central Bank } \\
\text { Independence }\end{array}$ & NA & NA & -18.75 & 14.03 & NA & NA & NA & NA & -2.71 & 1.98 & -1.29 & 1.93 \\
\hline $\begin{array}{l}\text { Exchange } \\
\text { rate regime }\end{array}$ & NA & NA & $11.79+$ & 5.50 & NA & NA & NA & NA & -0.33 & $0.08^{*}$ & $-0.39 *$ & 0.12 \\
\hline $\begin{array}{l}\text { Summary } \\
\text { Statistics }\end{array}$ & & & & & & & & & & & & \\
\hline Adjusted $\mathrm{R}^{2}$ & 0.10 & & 0.11 & & 0.43 & & 0.44 & & 0.49 & & 0.46 & \\
\hline F-statistic & 4.54 & & 3.46 & & 36.69 & & 39.39 & & 30.06 & & 25.37 & \\
\hline p-value & 0.00 & & 0.00 & & 0.00 & & 0.00 & & 0.00 & & 0.00 & \\
\hline
\end{tabular}

Note: highlighted values are statistically significant at conventional levels of significance.

In sum, our different strands of evidence provide complementary evidence for the pendulum hypothesis. Both the gold standard and the recent price stability regime had considerable credibility while the Bretton Woods era (with the exception of Germany and Switzerland did not). Institutional factors like central bank independence enhanced credibility. Finally in the recent period, countries adhering to formal inflation targeting had great credibility than those which do not-a point to be further developed in section 6 . 


\section{Inflation Targeting as a Credibility Enhancing Policy Strategy}

In the past two decades, since New Zealand first pioneered its use, a number of advanced countries (e.g., Canada, Australia, New Zealand, The UK, Norway and Sweden) have become inflation targeters. There is considerable evidence that IT improves central bank credibility over non IT monetary policy strategies that focus on maintaining low inflation (Walsh 2009). The evidence is not overwhelming that advanced country IT central banks have delivered better inflation performance than non It central banks (Ball and Sheridan 2005) ${ }^{9}$. But in the case of emerging countries the superiority of IT is clear. Some additional new evidence presented below further reinforces these conclusions.

The main advantage of IT for enhancing credibility is that it is a superior means of anchoring inflation expectations. It does this by clearly stating the target and communicating its intentions on how to maintain it. Walsh (2009), and others, explain that IT has greater transparency than other monetary policy strategies and is more accountable to the public. Below we provide some evidence that in the recent PS regime, IT countries had greater central bank credibility than their non IT counterparts.

\section{Inflation Performance}

First, we review the evidence on inflation performance across the world (figure 11). The figure shows IFS annual data on CPI inflation over the past 8 years for the world

\footnotetext{
${ }^{9}$ Serious reservations have been raised about their methodology and the interpretation of their results by Geraats (2014).
} 
divided into the following categories: Eurozone; Advanced, Advanced IT, Emerging Countries and Emerging Countries IT.

\section{Figure 11. Inflation by country groups}

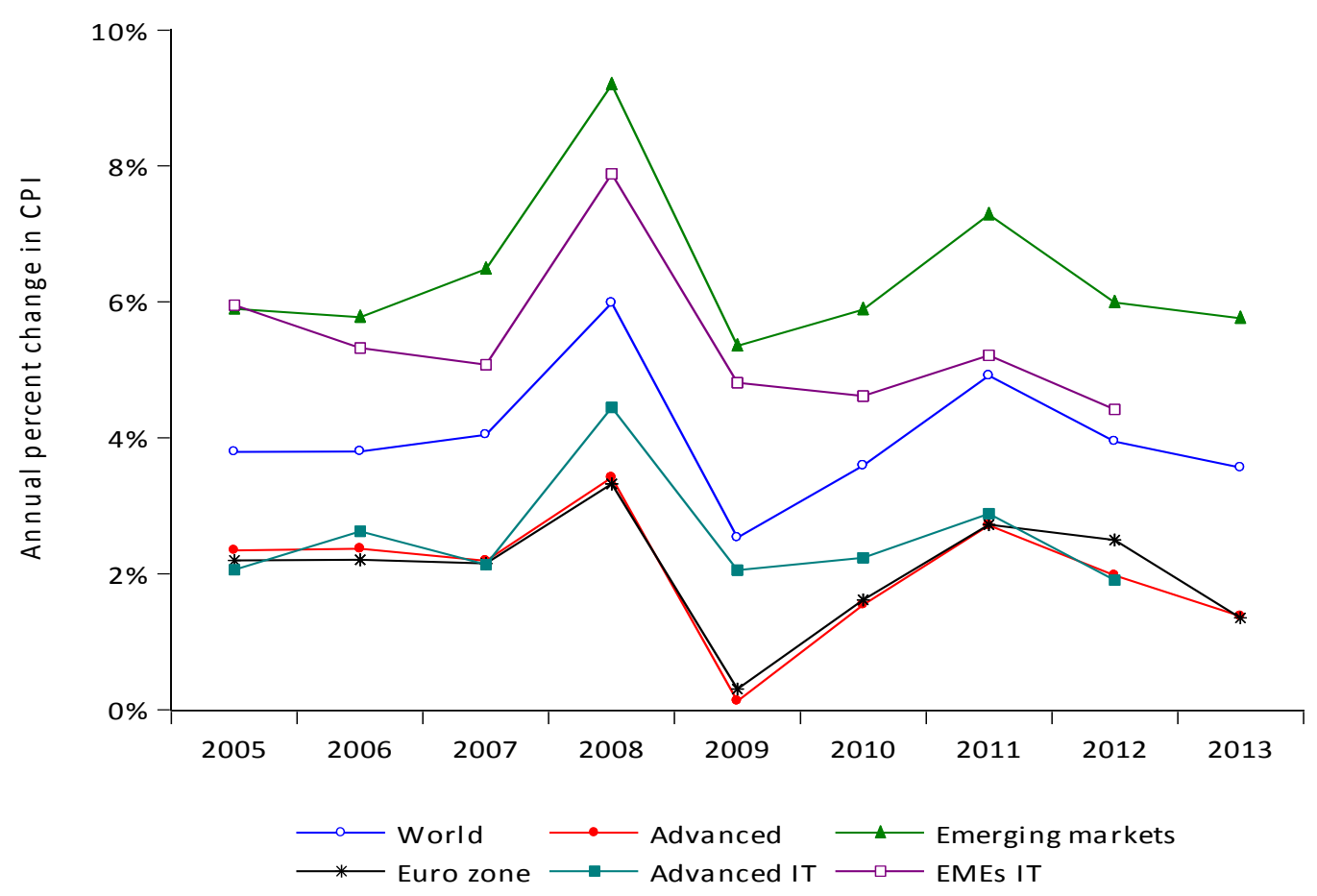

The first thing to note is that there is little difference in overall inflation between all advanced countries and the Eurozone. Second there is less volatility in inflation in advanced countries with IT and they are consistently much closer to the roughly $2 \%$ inflation target that advanced countries have typically adopted. Third, emerging countries with IT do consistently deliver better inflation performance than emerging market countries in general. Finally, we see that while there is no apparent convergence in inflation performance between the countries that do not have IT (EMEs and the World group) the differential in inflation in emerging 
countries with IT and emerging countries more generally rises as we get closer to the present and as a result, inflation in IT emerging countries is slowly converging to inflation in advanced countries. These results echo those by Walsh (2009) and others.

\section{Transparency}

One of the advantages of inflation targeting is that it embodies greater transparency than non IT regimes. Using the Dincer-Eichengreen (2007) annual index ( also see Dincer and Eichengreen 2014), made up of 15 indicators of transparency for 105 countries updated by Siklos (2014), where the index ranges from 0 to 15 we compare in figure 12 the transparency index score between advanced IT countries with the mean transparency index score for all countries in the sample.

\section{Figure 12. Transparency: advanced IT vs whole IT sample}

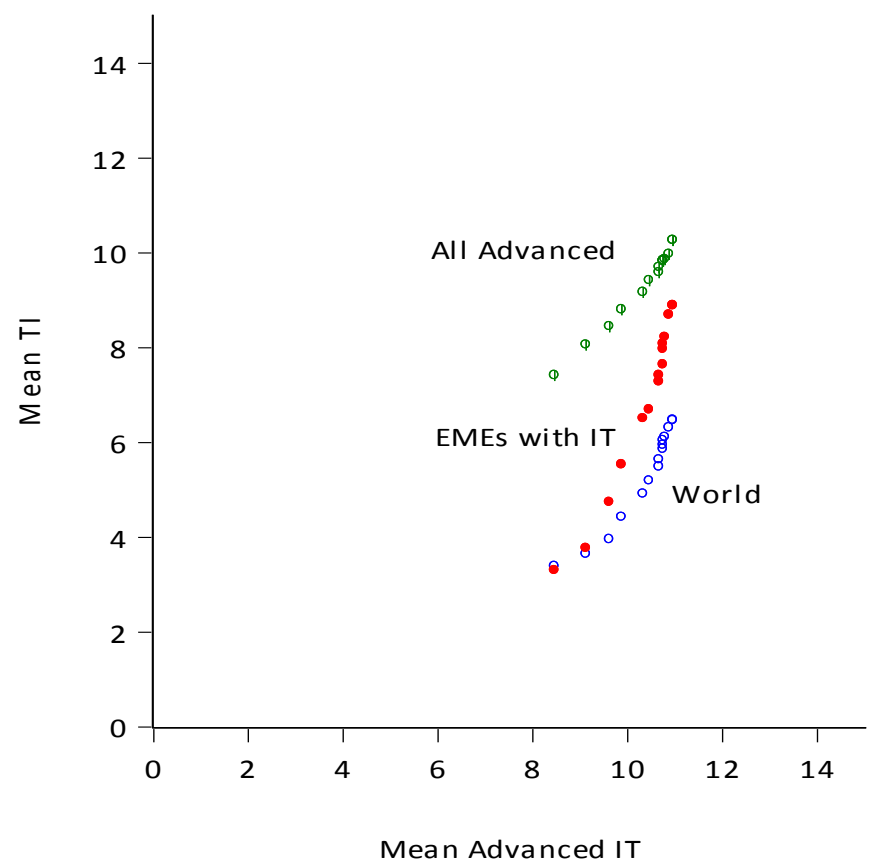

Note: The horizontal axis measures mean overall transparency (sum of 15 categories that sum up to the transparency index in advanced economies with numerical inflation targets (IT; IMF definition). The vertical axis measures mean overall transparency (i.e., TI) for the country groupings labelled in the figure. Each circle represents an annual observation. The world consists of all 105 economies in the sample. 
The figure is drawn such that the dots when transparency is low begin in 1998 and, with few exceptions, rises over time until 2013. We see from figure 12 that emerging countries with IT start in 1998 at the same point as the world but begin to converge rapidly towards the advanced countries. Not only do the emerging countries adopt IT very quickly but they become more transparent.

Figure 13. Transparency by country groups

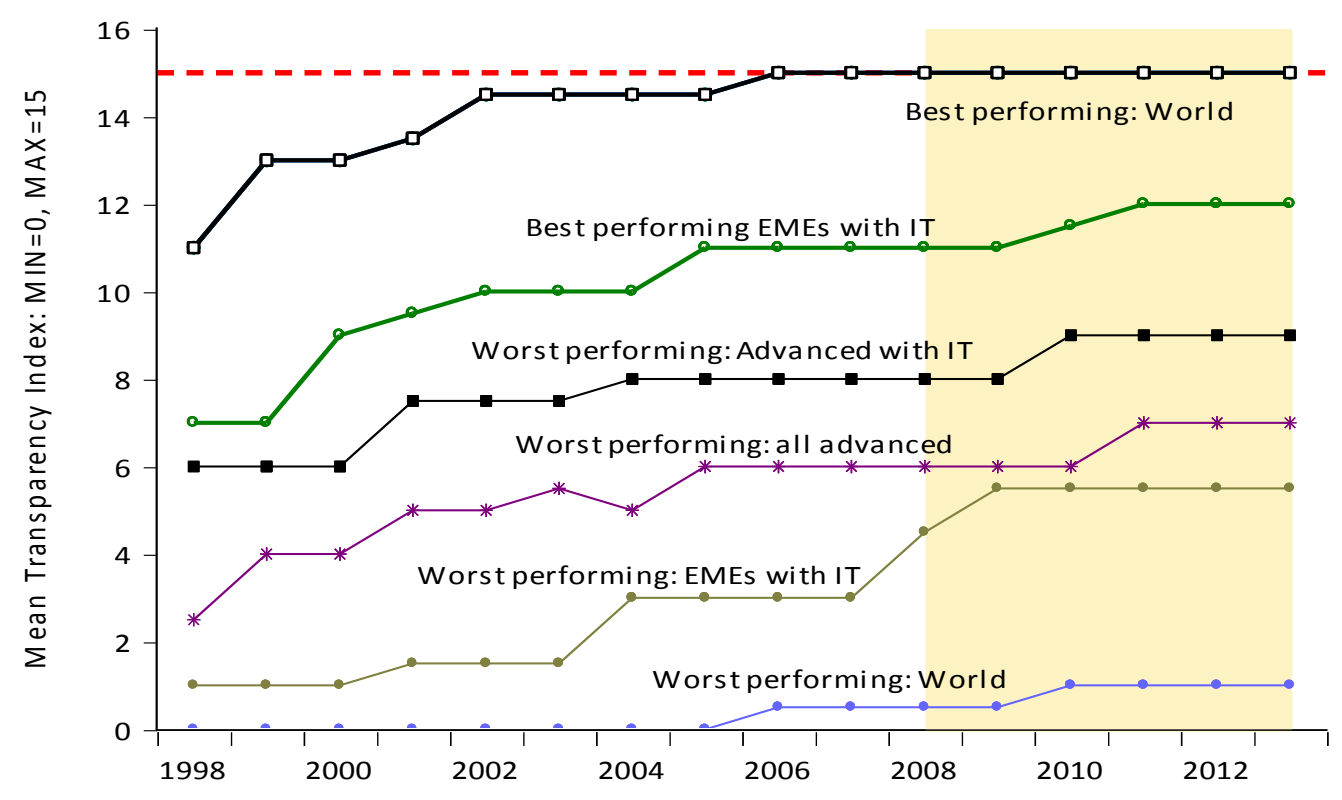

Note: the TI (also see figure 12) for the worst performing economy and the best performing economy for each category of economy shown (i.e., EME, World, Advanced), depending on whether they follow a numerical inflation target (IT) or not.

We next show the transparency index data in a time series format with the country groupings clearly shown. See figure 13 . The figure shows that the range of transparency across central banks in the world remains quite large. Even the worse performing EMEs easily outperform the worst in the world. Hence, in the emerging market countries is also clearly associated with much greater transparency. Indeed 
the best emerging countries with IT outperform the 'least' transparent or worst performing advanced countries. Finally, we note that by 2006 the best performing central banks in the world with respect to transparency have reached the maximum score of 15 by 2006 .

\section{Inflation and Transparency}

We now turn to the relationship between inflation and transparency. See figure 14 . The figure shows that there is a strong, statistically significant and negative relationship between inflation performance (vertical axis) and transparency (horizontal axis) for EMEs which adopted IT (left hand side plot). However we don't find such a relationship for the entire emerging market group of countries (not shown). The slope is also negative but the coefficient is insignificant for the world as a whole (middle plot). Finally, we do not find a link between transparency and inflation for advanced countries because they have largely converged both in terms of transparency and the level of inflation. Thus the figure suggests that transparency delivers benefits but these generally wear out after a number of years. After a CB becomes transparent it still needs to demonstrate competence and an ability to set the appropriate stance of policy and deal successfully with crises.

Figure 14. Inflation and transparency
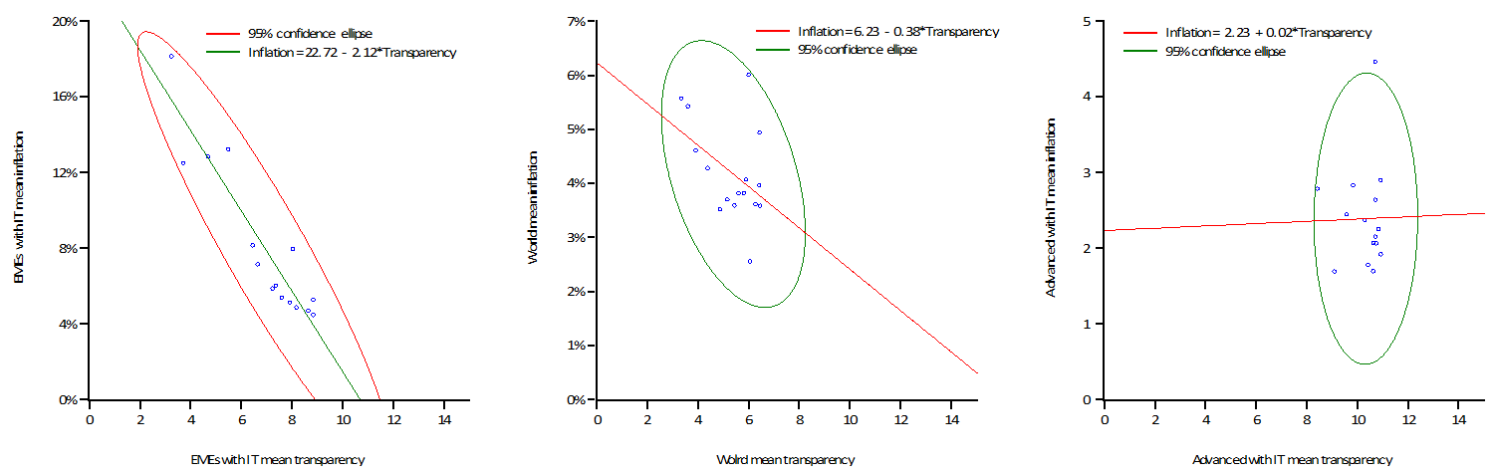


\section{Credibility}

We next turn to the issue of credibility. For the brief recent period examined in this section we use a simpler method to generate our measure of credibility than the one outlined in Bordo and Siklos (2014). Credibility is defined above as the squared difference between observed and target inflation. However target inflation is evaluated as the mean of inflation forecasts derived from an $\operatorname{AR}(1)$ and $\operatorname{IMA}(1,1)$ model using annual data whereas a more sophisticated approach that permits the target to be a function of one of three potential instruments of policy and is endogenously determined is used in Bordo and Siklos (2014). The results in figure 15 illustrate the evolution of credibility since 2005 . The data reveal that if inflation forecasts are generated with only the most recent data these indicate that credibility has improved since the bars are generally lower than if we assume that inflation forecasts are generated for a much longer sample. In other words, this figure provides indirect evidence that central banks with IT appear to have succeeded in anchoring inflation at lower levels. The notable exception to this result is the Eurozone (middle figure) which does not refer to itself as an inflation targeting central bank. 


\section{Figure 15. Credibility indicator}
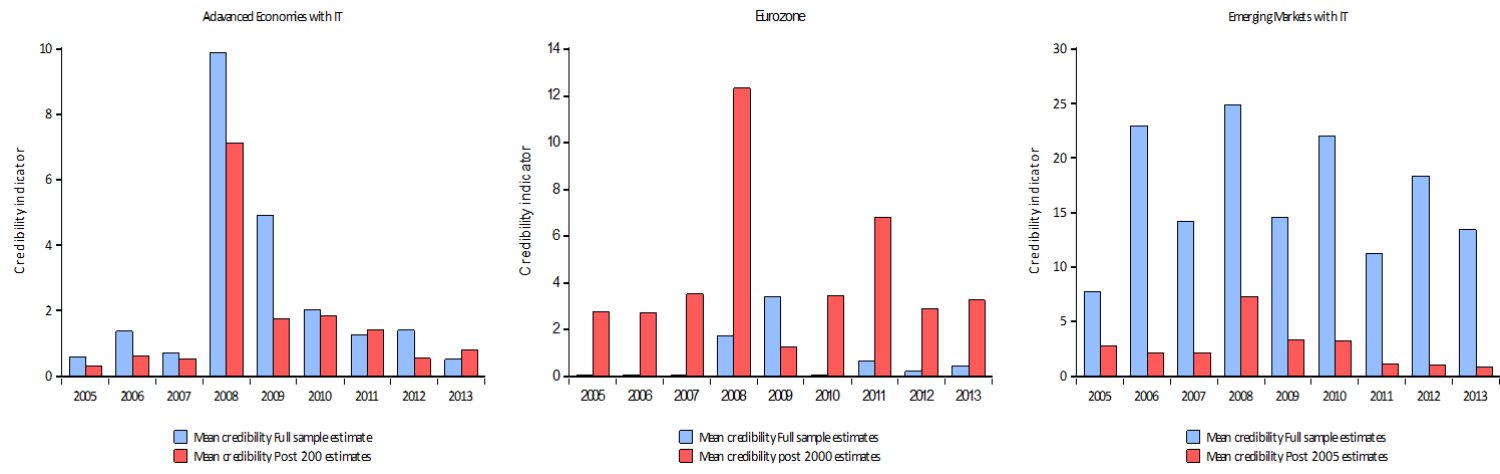

Finally, we present some regressions which focus on the determinants of credibility for IT and non IT countries in various groupings. The dependent variable in the regressions is credibility, proxied as the square of the forecast error where the inflation forecast is generated by estimates from two time series models: an AR(1) and an integrated moving average of order 1 . The mean of the two inflation forecasts is then taken as the proxy for the central bank's inflation objective. This implies that a form of inflation forecasting targeting is assumed. Our results, therefore, should be viewed as illustrative and tentative about the determinants of credibility. The regressions for advanced countries with IT and emerging market countries with IT are panel regressions with fixed effects. The Eurozone and "world' regressions are time series regressions. The statistically significant coefficients are highlighted in bold. Tables 5 and 6 show the results for the advanced countries with IT. Table 7 shows the results for the Eurozone. Table 8 shows the results for the emerging countries with IT. Finally Table 9 shows the results for the world. 
Table 5. Determinants of credibility, advanced countries with IT, 1998-2012

\begin{tabular}{|c|c|c|c|c|}
\hline \multicolumn{4}{|c|}{$\begin{array}{l}\text { Dependent Variable: } \\
\text { Credibility proxy - Advanced Economies with Inflation Targeting }\end{array}$} & \\
\hline \multicolumn{4}{|l|}{ Cross-sections included: 12} & \\
\hline \multicolumn{5}{|l|}{ Total pool (unbalanced) observations: 175} \\
\hline Variable & Coefficient & Std. Error & t-Statistic & Prob. \\
\hline Constant & 7.80 & 4.89 & 1.60 & 0.11 \\
\hline Lagged credibility & 0.02 & 0.08 & 0.28 & 0.78 \\
\hline Transparency index & -0.55 & 0.47 & -1.18 & 0.24 \\
\hline Net lending/borrowing as a \% of GDP & -0.50 & 0.14 & -3.70 & 0.00 \\
\hline Current account balance as a $\%$ of GDP & -0.53 & 0.14 & -3.74 & 0.00 \\
\hline R-squared & 0.31 & & & \\
\hline Adjusted R-squared & 0.24 & & & \\
\hline
\end{tabular}


Table 6. Determinants of credibility, advanced countries with IT, 1998-2012

\begin{tabular}{|c|c|c|c|c|}
\hline \multicolumn{4}{|c|}{$\begin{array}{l}\text { Dependent Variable: } \\
\text { Credibility proxy - Advanced economies with Inflation targeting }\end{array}$} & \\
\hline \multicolumn{4}{|l|}{ Cross-sections included: 12} & \\
\hline \multicolumn{5}{|l|}{ Total pool (unbalanced) observations: 175} \\
\hline Variable & Coefficient & Std. Error & t-Statistic & Prob. \\
\hline Constant & 7.82 & 4.85 & 1.61 & 0.11 \\
\hline Lagged credibility & 0.01 & 0.08 & 0.14 & 0.89 \\
\hline Transparency index & -0.85 & 0.49 & -1.72 & 0.09 \\
\hline Net lending/borrowing as a \% of GDP & -0.50 & 0.13 & -3.69 & 0.00 \\
\hline Current account balance as a $\%$ of GDP & -0.55 & 0.14 & -3.88 & 0.00 \\
\hline $\begin{array}{l}\text { Interaction effect: Transparency index } \\
\text { and Inflation Targeting }\end{array}$ & 4.18 & 2.28 & 1.83 & 0.07 \\
\hline R-squared & 0.32 & & & \\
\hline Adjusted R-squared & 0.25 & & & \\
\hline
\end{tabular}


Table 7. Determinants of credibility, Eurozone, 1998-2013

\begin{tabular}{|c|c|c|c|c|}
\hline $\begin{array}{l}\text { Dependent Variable: } \\
\text { Credibility proxy - Eurozone }\end{array}$ & & & & \\
\hline Included observations: 16 & & & & \\
\hline Variable & Coefficient & Std. Error & t-Statistic & Prob. \\
\hline Constant & -0.80 & 3.62 & -0.22 & 0.83 \\
\hline Lagged credibility & -0.49 & 0.36 & -1.36 & 0.20 \\
\hline Transparency index & -0.18 & 0.26 & -0.70 & 0.50 \\
\hline Government debt as a \% of GDP & 0.04 & 0.04 & 0.90 & 0.39 \\
\hline Net lending/borrowing as a \% of GDP & -0.44 & 0.22 & -2.00 & 0.07 \\
\hline Current account balance as a $\%$ of GDP & -0.69 & 0.38 & -1.81 & 0.10 \\
\hline R-squared & 0.47 & & & \\
\hline Adjusted R-squared & 0.20 & & & \\
\hline
\end{tabular}


Table 8. Determinants of credibility, EME with IT, 1998-2013

\begin{tabular}{|c|c|c|c|c|}
\hline \multicolumn{5}{|c|}{$\begin{array}{l}\text { Dependent Variable: } \\
\text { Credibility proxy - Emerging Market economies with Inflation Targeting }\end{array}$} \\
\hline \multicolumn{4}{|l|}{ Included observations: 16} & \\
\hline \multicolumn{4}{|l|}{ Cross-sections included: 18} & \\
\hline \multicolumn{5}{|l|}{ Total pool (unbalanced) observations: 264} \\
\hline Variable & Coefficient & $\begin{array}{l}\text { Std. } \\
\text { Error }\end{array}$ & $\begin{array}{r}\mathrm{t}- \\
\text { Statistic }\end{array}$ & Prob. \\
\hline Constant & 64.88 & 68.50 & 0.95 & 0.34 \\
\hline Lagged credibility & -0.03 & 0.03 & -0.94 & 0.35 \\
\hline Transparency index & -5.64 & 2.19 & -2.58 & 0.01 \\
\hline General Government Expenditure as a \% of GDP & 0.09 & 2.63 & 0.03 & 0.97 \\
\hline Net lending/borrowing as a \% of GDP & -1.75 & 2.41 & -0.73 & 0.47 \\
\hline Current account balance as a \% of GDP & 2.37 & 1.31 & 1.81 & 0.07 \\
\hline R-squared & 0.16 & & & \\
\hline Adjusted R-squared & 0.08 & & & \\
\hline F-statistic & 2.08 & & & \\
\hline Prob(F-statistic) & 0.00 & & & \\
\hline
\end{tabular}


Table 9. Determinants of credibility, world economy, 1998-2013

\begin{tabular}{|c|c|c|c|c|}
\hline \multicolumn{5}{|c|}{$\begin{array}{l}\text { Dependent Variable: } \\
\text { Credibility proxy, World economy }\end{array}$} \\
\hline \multicolumn{4}{|c|}{ Included observations: 16} & \multirow[b]{2}{*}{ Prob. } \\
\hline Variable & Coefficient & Std. Error & t-Statistic & \\
\hline Constant & 4.65 & 5.59 & 0.83 & 0.42 \\
\hline Lagged credibility & -0.26 & 0.22 & -1.21 & 0.25 \\
\hline Transparency index & 0.83 & 1.01 & 0.83 & 0.43 \\
\hline $\begin{array}{l}\text { World Oil price } \\
\text { inflation }\end{array}$ & -0.11 & 0.04 & -2.67 & 0.02 \\
\hline R-squared & 0.46 & & & \\
\hline Adjusted R-squared & 0.32 & & & \\
\hline
\end{tabular}

The main findings from these tables are as follows:

(1) Consistent with the previous figures transparency does not seem to be related to credibility in advanced countries with IT. However, in Table 6 when credibility is interacted with a dummy set to one when the countries in the panel adopt IT, the transparency index coefficient becomes negative, an indication that transparency improves credibility. This is more than offset, however, by the coefficient on the IT dummy, an indication that advanced countries with IT saw a fall in credibility, other things being equal during the time they targeted inflation. This may be explained by the crisis of 2007-2013 which takes up almost half the sample 
and may be capturing other factors like quantitative easing and other unorthodox response measures.

(2) The net lending/borrowing (by the private sector) variable is also significant indicating that when bank lending rises central bank credibility falls;

(3) The Eurozone regressions in Table 7 sees no credibility bonus from transparency, conditional on the variables considered. The lending variable is also significant as in the case of the advanced countries.

(4) Tables 8 and 9 compare the emerging countries with IT with the "world" (essentially a proxy for no IT). Emerging countries with IT see a credibility bonus from greater transparency (this result holds even when we interact with IT and add in an IT dummy as in Table 6 for advanced countries; not shown). There is no credibility bonus in the rest of the world from greater transparency. Since the "world" includes the 30 countries that adopted IT this suggests that we are stacking the decks against the ITers and so the results suggest a significant link between the adoption of IT, greater transparency, and more central bank credibility.

Overall our empirics suggest that in general countries adopting IT have greater credibility and transparency than those without it. These results are most striking for the group of emerging market countries.

\section{Policy Lessons}

The historical and empirical approach taken in this paper reveals a pendulum in central bank credibility from the nineteenth century to the present. The recent 
popularity of monetary policy regimes which emphasize price stability (PS) has been characterized by a level of credibility that is similar to the one observed under the classical gold standard. However, the current regime is based on a more flexible fiat money system. The recent PS experience has been greatly enhanced by the adoption of inflation targeting (IT), and the evidence suggests that this has been especially true for some emerging market economies.

The financial crisis of 2007-2008 forced central banks to focus on lender of last resort actions and enact other policies to preserve financial stability. These actions involved working closely with the fiscal authorities and some observers have suggested that this turn of events has compromised their independence. Of course, even policy makers who place a heavy emphasis on the critical role of central bank autonomy also recognize the value of fiscal and monetary policies working in harmony.

Since the crisis central banks have been engaged in unorthodox quantitative easing policies which depart greatly from the traditional "bills only" approach. Moreover the evidence to date also points to the conclusion that through the crisis period the nominal anchor has held and inflation has remained low and stable while no policy regime formally referred to as consistent with inflation targeting has been abandoned. As the IMF pointed out recently, " inflation is the dog that didn't bite' (IMF 2013). Nevertheless, it is reasonable to pose the question: will central banks continue to remain credible when they promise to preserve a policy to maintain inflation low and stable? After all there are prominent voices arguing for higher inflation than we have experienced in recent years or to raise the levels at which 
inflation is considered to be low, in part to ease the burden of rising debt, to vanquish thoughts of slipping into a Japan style deflation, or because observed inflation rates remain well below explicitly stated targets. ${ }^{10}$

The recent financial crisis has also led to the call for central banks to elevate the goal of financial stability to the same level as price stability. This is based on the belief that the credit cycle will create future imbalances and future asset booms and busts and financial crises. Hence, CBs should head off these imbalances by preemptive monetary policy. However, such policies (assuming they work and do not backfire as occurred in the U.S. in 1929 and Japan 1990) may be problematic if they impinge on central banks main mandate for low and credible inflation. That is, the profession is still grappling with the nature of any possible trade-off that might exist between price stability and financial system stability. Part of the difficulty is that whereas the effects of various instruments of monetary policy are well understood the same is not the case for the variety of so-called macro prudential tools being used. It may well be the case that a regime that works well in 'normal times' needs to be suspended, and credibly so, during extraordinary or crisis times.

There are a number of recent illustrations suggestive of the difficulty in balancing the twin objectives of price and financial stability. For example recent concerns in Sweden and Norway over rising house prices led the Riksbank and Norges Bank to keep their policy rates higher than dictated by usual macro indicators demonstrating that the conventional tool of monetary policy, the policy interest

10 This is not the case everywhere. Spillover effects from ultra-loose monetary policies in the U.S. and other advanced countries, combined with domestic factors, have led to inflation rates that exceed inflation target objectives in economies such as Brazil. 
rate, can be a heavy-handed weapon to deal with asset price inflation (e.g. see Svensson 2014). Indeed, around the time this paper was written, the Riksbank did an about face and cut the repo rate around the time other central banks are beginning to talk more openly about raising their policy rates.

For the U.S., U.K. and Canada, the central banks have kept policy rates unusually low because they don't see inflation on the horizon and their economies continue to be recovering. But this can contribute to asset price inflation. In addition there is the potential loss of credibility if central banks decide to tighten monetary policy earlier than planned. Mark Carney of the Bank of England and Jim Bullard of the Federal Reserve have both said that markets are not preparing themselves for rate rises and the 2014 BIS Annual Report makes the same point. As a result, there is always the possibility that these central banks may make the one big mistake that will ruin their reputations as in the Ben Franklin quote earlier in the paper.

Several considerations are involved in determining the likelihood that central bank credibility and reputation will be adversely affected: (1) the use of the policy rate for multiple objectives can be a threat to $\mathrm{CB}$ credibility because it may give conflicting signals to the public. An historical example of this problem was the use of sterilized exchange market intervention by the Federal Reserve from 1962 to 1995 . Holding constant the question about its effectiveness, the FOMC in the mid-1990s decided to greatly down play its use because it threatened their new emphasis on credibility for low inflation (Bordo, Humpage and Schwartz 2014).

(2) The use of other macro prudential tools such as leverage ratios, loan to value ratios, liquidity ratios, margin requirements and capital ratios to stabilize the credit 
cycle may also be problematic. The problem is that by adding on extra tools to the CBs toolkit it may complicate the CBs mission. Again turning to history, in the 1950s and 60s many central banks used such instruments to influence the level and growth of credit and money. These policies ultimately were abandoned because they were not viewed as successful. CBs also influenced the allocation of credit to different sectors of the economy. This use of credit policy where the $\mathrm{CB}$ picks winners and losers, referred to as credit policy-- a form of fiscal policy according to Goodfriend (2012) may distort resource allocation and compromise CB independence. More important it may conflict with the central bank's main mandate which is to maintain price stability.

Thus, central banks may wish to exercise caution in joining the macro prudential bandwagon. The evidence on the existence of credit cycles is not yet overwhelming although many observers have argued that excessive credit growth was one of the principal culprits in the last financial crisis (e.g. see Drehmann and Juselius 2013). Part of the difficulty is that financial crisis can originate from the non-banking sector as well and their role in the transmission mechanism is not yet fully understood. There is no consensus macro model yet to back up the widespread use of these policies unlike the workhorse New Keynesian models currently being adapted to incorporate financial sector influences. Also it is not clear that central banks rather than other agencies can most efficiently conduct these policies. Many countries delegate these tasks to other agencies and the Treasury. In addition there are few serious macro models to back up the widespread use of these policies. Protecting 
the payments system and deposit taking institutions via a lender of last resort following Bagehot Rule like behavior may yet prove to be sufficient (Bordo 2014). 


\section{References}

Liaquat Ahamed (2010) The Lords of Finance. Penquin Books

Walter Bagehot (1873) Lombard Street. London

Lawrence Ball and N. Sheridan (2005) “Does Inflation Targeting Matter?" in Ben Bernanke, Michael Woodford (eds) The Inflation Targeting Debate, NBER Studies in Income and Wealth. Chicago: University of Chicago Press

Andreas Beyer,Vitor Gaspar, Christina Gerberding and Otmar Issing, ( 2013),"Opting Out of the Great Inflation: German Monetary Policy after the Breakdown of Bretton Woods" in Michael D. Bordo and Athanasios Orphanides (eds) The Great Inflation;

The Rebirth of Modern Central Banking. University of Chicago Press for the NBER

Robert Barro, R., (1979) “Money and Output in Mexico, Colombia, and Brazil” in: Short-Term Macroeconomic Policy in Latin America, edited by Jere Behrman and James Hanson, NBER Books, pp. 177-200.

Ben Bernanke, (2013), The Federal Reserve and the Financial Crisis (Princeton, N.J.: Princeton University Press).

Ben Bernanke, and F. Mishkin, (1997), "Inflation Targeting: A New Framework for Monetary Policy?", NBER Working Paper No. 5893.

A.Bianchi, (2008) “La Autonomía del Banco Central de Chile: Origen y Legitimación", Economic Policy Papers No. 26, Central Bank of Chile.

Michael Bordo (2014) "Rules for a Lender of Last Resort; an Historical Appraisal" Journal of Economic Dynamics and Control, Special Issue: Frameworks for Central Banking in the Twentieth Century (forthcoming) 
Michael Bordo and Pierre Siklos (2014) "Central Bank Credibility and Reputation: An Historical Exploration" Norges Bank Conference June

Michael Bordo, Owen Humpage and Anna Schwartz (2014) Strained Relations: U.S. Monetary Policy and Foreign Exchange Operations in the Twentieth Century. Chicago: University of Chicago Press

Michael Bordo and Athanasios Orphanides (2013), The Great Inflation: The Rebirth of Modern Central Banking. Chicago: University of Chicago Press for the NBER

Michael Bordo and John Landon Lane (2013a) "Does Expansionary Monetary Policy Cause asset Price Booms: Some Historical and Empirical Evidence" NBER Working Paper 19584

Michael Bordo and John Landon Lane (2013b), "What Explains House Price Booms?: History and Empirical Evidence" NBER Working Paper 19584

Michael Bordo and David Wheelock (2013) "The Promise and Performance of the Federal Reserve as Lender of Last Resort 1914-1933" in Michael D Bordo and Will Roberds (eds) A Return to Jekyll Island. New York: Cambridge University Press

Michael Bordo and Joseph Haubrich (2012), "Deep Recessions, Fast Recoveries and Financial Crises: Evidence from the American Record" NBER Working Paper 18194 June

Michael Bordo, Chris Erceg, Andrew Levin and Ryan Michaels (2007) "Three Great American Disinflations" NBER Working paper No. 12982 March 
Michael Bordo and Ronald Macdonald (2005) "Interest rate interactions in the Classical Gold Standard: 1880-1914: Was There Monetary Independence?' Journal of Monetary Economics March

Michael Bordo and Ronald Macdonald (2002) "The Interwar Gold Exchange Standard; Credibility and Monetary Independence" Journal of International Money and Finance

Michael Bordo and Hugh Rockoff (1996) "The Gold Standard as a Good Housekeeping Seal of Approval” Journal of Economic History. June

Michael Bordo and Finn Kydland (1995) "The Gold Standard as a Rule: An Essay in Exploration" Explorations in Economic History. October

Michael Bordo and Bernhard Eschweiler (1994) "Rules, Discretion and Central Bank Independence: The German Experience 1880-1989" in Pierre Siklos (ed) Varieties of Monetary Reform: Lessons and Experience on the Road to Monetary Union. Boston: Kluwer Academic Publishers.

Michael Bordo and Anna Schwartz (1994) "The Specie Standard as a Contingent Rule: Some Evidence for Core and Peripheral Countries, 1880-1990" NBER Working paper 4860

Michael Bordo (1993) "The Bretton Woods International Monetary System: An Historical Overview" in Michael D Bordo and Barry Eichengreen (eds) A Retrospective on the Bretton Woods System. Chicago: University of Chicago Press for the NBER.

Michael Bordo (1990) "The Lender of Last Resort: Alternative Views and Historical Experience" Federal Reserve Bank of Richmond Economic Review .March 
Michael Bordo (1981) "The Classical Gold Standard: Some Lessons for Today" Federal Reserve Bank of St. Louis Review, Vol 63, No.6 May

Braun-Llona, J., M. Braun-Llona, I. Briones, J. Díaz, R. Lüders and G. Wagner, 1998, “Economía Chilena 1810-1995. Estadísticas Históricas”, Documento de Trabajo IEPUC, $N^{\circ} 187$.

Bravo, H. F., and C. Garcia, 2002, "Una Revisión de la Transmisión Monetaria y el Pass-Through en Chile", Working Paper №149, Central Bank of Chile.

Karl Brunner (1983), “Has Monetarism Failed?”, Cato Journal 3 (Spring), 23-62.

Forrest Capie (2010) The Bank of England 1950s to 1979. Cambridge: Cambridge University Press

G. Calvo, L. Leiderman and C. Reinhart ( 1999) "Inflows of Capital to Developing Countries in the 1990s" Journal of Economic Perspectives, Vol 10, No.2 pp 123-139

Carrasquilla, A., 1996, "Dimensiones fiscales de una inflación moderada: el caso colombiano", Borradores de Economía No. 55, Banco de la Republica.

Carstens, A. and A. Werner, 2000, "Mexico's monetary policy framework under a floating exchange rate regime" Money Affairs, Vol. 13 No.2.

L.F. Cespedes and C. Soto (2005) "Credibility and Inflation Targeting Implementation in an Emerging Market: The Case of Chile" Working Paper No.312, Central Bank of Chile

L.F. Cespedes and C. Soto (2007), "Credibility and Inflation Targeting in Chile" in Monetary Policy under Inflation Targeting, (eds) F. Mishkin, K. Schmidt-Hebbel and Norman Loayza, chapter 14, pp 547-578, 
V. Corbo and L. Hernandez (2005) "Ochenta Años de Historia del Banco Central de Chile" Economía Chilena *(3): pp 5-27.

V. Corbo (1998) "Reaching One Digit Inflation: The Chilean Experience" Journal of Applied Economics, vol 1 No.1 pp 123-163.

J.F. Cortes (2013) “Una Estimación del Traspaso de las Variaciones en el Tipo de Cambio a los Precios en México" Working Paper 13-02, Banco de México

Cukierman, Alex (1986), "Central Bank Behavior and Credibility: Some Recent Theoretical Developments", Federal Reserve Bank of St. Louis Review (May): 5-17.

D. Chiquiar, E. Noriega, and M. Ramos-Francia, 2010, "A Time Series Approach to Test a Change in Inflation Persistence: The Mexican Experience", Applied Economics, vol. 42, pp. 3067-3075.

De Gregorio, J., A. Tokman and R. Valdes, 2005, "Flexible Exchange Rate with Inflation Targeting in Chile: Experience and Issues", Working Paper No. 540, Research Department, IDB

De Long, B. (1997), “America's Peacetime Inflation: the 1970s”, in Reducing Inflation: Motivation and Strategy, Edited by C.D. Romer and D.H. Romer (Chicago: University of Chicago Press)

Riccardo Di Ceccio and Edward Nelson (2013) "The Great Inflation in the United States and the United Kingdom: Reconciling Policy Decisions and Data Outcomes" in Michael Bordo and Athanasios Orphanides (eds) The Great Inflation: The Rebirth of Modern Central Banking. Chicago: University of Chicago Press for the NBER. 
Dincer N., and B. Eichengreen (2014) "Central Bank Transparency and Independence: Updates and New Measures", International Journal of Central Banking, March : 189-253.

Dincer, N. and B. Eichengreen (2007), "Central Bank Transparency: Where, Why, and With What Effects?", NBER working paper 13003, March, http://www.nber.org/papers/w13003

Drehmann and M. Juselius ( 2013), “ Evaluating Early Warning Indicators of Banking Crises: satisfying Policy Requirements" BIS Working Paper 421, August

Echeverry, J.C., 1996, "The Rise And Perpetuation Of A Moderate Inflation, Colombia 1970-1991", Borradores de Economía No. 50, Banco de la Republica.

Eichengreen, B. (1997), "The Gold Standard Since Alec Ford" in Barry Eichengreen and Marc Flandreau (eds) The Gold Standard in Theory and Practice. Second Edition. London: Routledge.

Barry Eichengreen (1992) Golden Fetters. New York: Oxford University Press

Fellner, William (1976), Towards a Reconstruction of Macroeconomics: Problems of Theory and Policy (Washington, D.C.: American Enterprise Institute).

Milton Friedman and Anna Schwartz (1963) A Monetary History of the United States: 1867 to 1960. Princeton: Princeton University Press

Garcia, C. and J. Restrepo, 2001, "Price Inflation and Exchange Rate Pass-Through in Chile", Working Paper №128, Central Bank of Chile.

Garcia-Verdu, 2012, "Evolución de las Expectativas de Inflación en México” Working Paper 12-06, Banco de México. 
Geraats. P. (2014), "Monetary Policy Transparency", in J. Foessbaeck and L. Oxelheim (Eds), Oxford Handbook of Institutional and Economic Transparency (Oxford: Oxford University Press), pp. 68-97.

Gomez, J., 2000, "Wage indexation, inflation inertia, and the cost of disinflation." Borradores de Economía No. 198. Banco de la República.

Goodfriend, M. (1986), “Monetary Mystique: Secrecy and Central Banking”, Journal of Monetary Economics 17 (January): 63-92.

Goodfriend, M., and R. King (2013), “The Great Inflation Drift”, in M.D. Bordo and A. Orphanides (Eds), The Great Inflation: The Modern Rebirth of Central Banking Chicago: University of Chicago Press.

Goodfriend M. (2012) "The Elusive Promise of Independent Central Banking" Keynote Lecture, 2012 BOJ-IMES Conference, Institute for Monetary and Economic Studies, Bank of Japan, May 30-31

Marvin Goodfriend (1993) “Interest Rate Policy and the Inflation Scare Problem 1979-1992" Federal Reserve Bank of Richmond Quarterly Vol 79/1 Winter.

Haberler, Gottfried (1980), "Notes on Rational and Irrational Expectations", reprint 111, American Enterprise Institute (March).

International Monetary Fund ( 2013) “ The Dog That Didn't bark: Has Inflation Been Muzzled or Was it Just Sleeping?" World Economic Outlook, Chapter 3, April.

Kalmanovitz, S. and M. Avella, 1998, "Barreras del desarrollo financiero: las instituciones monetarias colombianas en la década de 1950", Borradores de Economía No. 104, Banco de la Republica. 
Kozicki, S., and P.A. Tinsley (2009), "Perhaps the 1970s FOMC Did What it Said it Did", Journal of Monetary Economics 56: 842-855.

Landerretche, O., F. Morandé and K. Schmidt-Hebbel, 1999, "Inflation Targets and Stabilization in Chile", Working Papers No. 55, Central Bank of Chile.

Levin, A., and J. Taylor (2013), "Falling Behind the Curve: A Positive Analysis of StopStart Monetary Policies and the Great Inflation", in M.D. Bordo and A. Orphanides (Eds.), The Great Inflation: The Modern Rebirth of Central Banking (Chicago: University of Chicago Press).

Lopez, A., 1990. "La estabilización de la economía colombiana después de la Guerra de los Mil Días y el período de transición monetaria comprendido entre 1903 y 1923", in: "El Banco de la República: antecedentes, evolución y estructura", edited by Adolfo Meisel, Banco de la Republica.

C. Marichal (1994), "Nacimiento y Desarrollo del Banco Nacional de México" in "La Formación de los Bancos Centrales en España y América Latina", vol I, ( eds) P. Tedde and C. Marichal, Banco de Espana.

C. Marichal (2006) "Debates sobre orígenes de la banca central en México" in “México-España; Economías paralelas?” (eds) A Gomez, G. Marquez and R. Dobado, México, Fondo de Cultura Económica.

Martinez, L. and A. Werner, 2002, "The exchange rate regime and the currency composition of corporate debt: the Mexican experience", Journal of Development Economics, vol. 69, pp. 315- 334.

Meisel, A., 1992, "Free Banking in Colombia", in: The Experience of Free Banking, edited by Kevin Dowd, Routledge - Taylor \& Francis. 
Meltzer, Allan (2001) A History of the Federal Reserve, Volume 1: 1913-1951

(Chicago: University of Chicago Press).

Morande, Felipe and Schmidt -Hebbel Klaus (2001) "Política Monetaria y Metas de Inflación en Chile" Revista Estudios Económicos, issue 7 Banco Central de Reserva del Perú

A Perez-Lopez (1996) “Un Estudio Econométrico sobre Inflación en México" Working Paper 9604, Banco de México

M. Ramos-Francia and A. Torres (2006), "Inflation Dynamics in Mexico; a Characterization Using the New Phillips Curve," Working paper 06-15, Banco de Mexico.

Restrepo, Jorge E , Luis Salomo y Rodrigo Valdes, (2008) “Macroeconomía, Política Monetaria y Patrimonio del Banco Central” Working Paper No. 497, Central Bank of Chile

Reviez, A., "Evolution of the Colombia peso, within the currency bands, nonlinearity analysis and stochastic modeling.' Revista Economía del Rosario, Vol 5(1), pp 37-91.

Sanchez, F., A. Fernandez and A. Armenta, 2007, "Historia monetaria de Colombia en el siglo XX: grandes tendencias y episodios relevantes", in: "Economía colombiana del siglo XX. Un análisis cuantitativo" edited by: J. Robinson and M. Urrutia, Banco de la Republica and Fondo de la Cultura Económica.

Sanhueza, G. (1999). "La Crisis Financiera de los Años 80 en Chile: Análisis de sus Soluciones y su Costo." Economía Chilena 2(1): 43-68. 
Siklos, P.L. ( 2008) “ The Fed's Reaction to the Stock Market During the Great Depression: Fact or Artefact?, Explorations in Economic History 45(2) : 164-184.

Siklos, P.L. (2002), The Changing Face of Central Banking (Cambridge: Cambridge University Press).

Silber, W.L. (2012), Volcker (New York: Bloomsbury Press).

T. Sargent, N. Williams, and T. Zha, 2009, "The Conquest of South American Inflation" Journal of Political Economy, vol. 117, No. 2, pp. 211-256

John Singleton (2010) Central Banking in the Twentieth Century. Cambridge: Cambridge University Press.

Svensson, L.E.O. ( 2014) “ To Lean or Not to Lean: The Swedish Experience”, Dinner Speech, SNB Research Conference 2014 , Zurich , September 26-27, 2014.

John B. Taylor (2007) "Housing and Monetary Policy" in Housing Finance and Monetary Policy. Federal Reserve Bank of Kansas City

E. Turrent-Diaz (2007) “Las Tres Etapas de la Autonomía del Banco Central en México" Working paper 07-10, Banco de México

Urrutia, M., M. Hofstetter and F. Hamann, (2014), "Inflation Targeting in Colombia: 2002-2012", IDB Working Paper No. IDB-WP-487, Inter-American Development Bank.

Vargas, H., (2005), "Exchange rate policy and inflation targeting in Colombia", IDB Working Paper No. 539, Inter-American Development Bank. 
Wilford, D.C. and J.R. Zecher, (1979), "Monetary Policy and the Balance of Payments in Mexico, 1955-75", Journal of Money, Credit and Banking, vol. 11, No. 3, pp. 340348.

Walsh, C., (2009), “Inflation Targeting: What Have We Learned?", International Finance, 12:2, 195-233. 